\title{
Bridal Shower: \\ Tren Perayaan Melepas Masa Lajang di Kalangan Perempuan di Kota Makassar
}

\author{
Astina \\ Universitas Hasanuddin \\ astina120897@gmail.com
}

\begin{abstract}
Bridal shower is a celebration of letting go of single status adopted from European and American culture. This has become a new form of ceremony held by a friendship group, as the bridesmaids. It examines the adoption process of bridal shower, the process of the celebration itself, and the meaning of such celebration from both bridesmaids and bride to be.
\end{abstract}

This qualitative research was conducted in the capital city of Makassar, It involved 14 informant whose age between 21 and 26 years. They consist of eight bridesmaids who make and plan a bridal shower, four bride to be who have received a surprise bridal shower celebration, and two party planners who have five years experience in organizing such celebration. Data was collected using the combination of in-depth interview and observation, examining 18 cases of bridal shower celebration.

The study indicates that bridal shower is conducted as a moment of separation and as a form of support from bridesmaids to the bride to be who will be heading to a new life. The reasons behind the celebration of bridal shower includes the presence of group awareness, moment of letting go of friend, as a form of group support, following trend, and as a form of reciprosity. The celebration of bridal shower includes five stages. First, welcoming bride to be with a number of surprises. Second, embedding of attributes with the use of a crown to show the privileges of the bride to be and a shawl as a medium for writing funny messages that generally relate to the transfer of status and sexuality. Third, playing games in the form of questions with sanctions. Fourth, disclosing messages and impressions from the bridesmaid to the bride to be; Fifth, ending up eating together while reminiscing. Although each stage has its own purpose, they are all meant to make the bride to be happy. Bridal shower celebration is full of meanings, namely: as a status switch, as a medium for self reflection and introspection, and as a moment for friendship group existence. Bridesmaids support is very significant considering that the transition from one status to another and incoming new responsibilities both create fears to the bride to be. Thus, bridal shower celebrations become a transitional ritual at the critical moment because, on the one hand, bride to be has already "bound" by the acceptance of groom's proposal; on the other hand, the status of marriage has not been grasped, a moment which Van Gennep (1960) termed as "rites de passage". A bridal shower celebration is a moment in which the bride to be stretches herself towards getting married. Bridal shower is also a medium for reflection and introspection, accompanied by the expression of messages of "farewell", discourses or advice to the bride to be. Bridal shower is also a moment to show the existence of a friendship group through uploading photos/videos of bridal shower celebration on social media and an event to display status, for both bridesmaids and brides to be.

Keywords: bridal shower, bridesmaids, bride to be, celebration, and party planner. 


\section{Pendahuluan}

Pernikahan adalah momentum sakral yang didambakan hampir semua manusia. Perkawinan tidak hanya mengenai ikatan lahir batin dan proses peralihan status seseorang, tetapi pernikahan juga mencakup keseluruhan prosedur yang terjadi dalam proses penyelenggaraan dan perayaan suatu pernikahan mulai dari prosesi pelamaran hingga pesta pernikahan selesai (Millar 2009:86).

Pernikahan merupakan sesuatu hal yang penting, semua masyarakat memiliki tata cara pelaksanaan pernikahannya masingmasing. Tata cara tersebut ada yang sama pada beberapa kelompok dan ada pula yang berbeda. Tetapi secara umum, pernikahan pada setiap kelompok masyarakat memiliki tahapan-tahapan. Misalnya pada etnis BugisMakassar tahapan-tahapan yakni, mammanu'manu', madduta, mappettuada, mappenre balanca dan pesta/tudang botting (mappasau, mappacci, akad nikah/kawing soro) (Husain 2012:43-47).

Sebagaimana upacara perkawinan pada banyak masyarakat di Indonesia, perkawinan etnis Bugis-Makassar juga telah banyak mengalami perubahan, terutama dengan masuknya unsur-unsur modern. Misalnya, pelaksanaan mappettuada, pernikahan dan resepsi yang dulunya digelar di rumah dengan memasang tenda, kini dilaksanakan di gedung ataupun di hotel. Meskipun ada modifikasi dalam rangkaian kegiatan perkawinan tersebut, unsur-unsur utamanya tetap dipertahankan. berkaitan erat dengan rasa persahabatan dan jaringan keluarga di antara perempuan, terutama selama masa transisi peralihan status (Montemurro 2002:83). Tradisi ini dilakukan berlandaskan rasa kesetiaan atau kewajiban kepada teman atau kerabat untuk menunjukkan kesetiakawanan dan solidaritas sosial. Selain itu, bridal shower juga sebagai bentuk kesetaraan gender bagi perempuan (Finol 1994:88) karena perayaan serupa juga dilakukan oleh laki-laki namun hanya sebatas untuk kesenangan semata.

Tradisi bridal shower berawal dari Belanda pada abad ke-16, kemudian pada tahun 1960-an menyebar dan berkembang ke Brusel, Amerika, Australia, New Zealand, hingga ke negara-negara kawasan Asia mengikuti migrasi orang Belanda. Di Indonesia, seremoni ini ternyata telah diadopsi dan mulai popular sejak tahun 2011 setelah kegiatan yang sama dilakukan oleh para selebritis ataupun selebram, seperti Raisa Adriana, Laudya Cintia Bella, Nina Zatulini, Nabila Gardena, hingga Rachel Venya dan dipublikasikan melalui berbagai macam media. Sebagai public figure yang memiliki banyak penggemar, maka apa yang mereka lakukan cenderung ditiru oleh para penggemar mereka dan masyarakat secara umum.

Persebaran tradisi seperti ini menurut Koentjaraningrat (2009:164) dapat berlangsung secara cepat, dan seringkali tanpa kontak yang nyata antara individu melainkan karena adanya alat-alat penyiaran yang sangat efektif, seperti surat kabar,

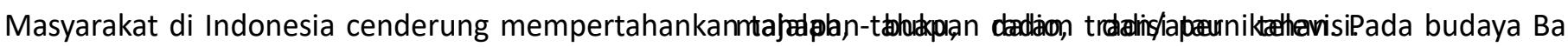
perayaan peralihan status seorang perempuan dari status lajang ke status menikah.

Bridal shower dilakukan para sahabat dekat dengan memberikan hadiah kepada perempuan calon pengantin berupa uang, peralatan elektronik, perabotan rumah tangga, alat kontrasepsi, serta barang-barang yang fungsional setelah menikah. Seremoni ini Fenomena bridal shower merupakan salah satu bukti adanya persebaran budaya yang terjadi melalui perkembangan teknologi komunikasi saat ini. Ini menjadikan masyarakat dapat secara tidak langsung mengadopsi tradisi atau budaya lain.

Di Indonesia, seremoni baru yang dilakukan hanya oleh kaum perempuan ini 
sangat identik dengan kemewahan karena perayaan ini umumnya di gelar di hotel, café atau di restoran mewah, dilengkapi dekorasi yang menarik, sehingga biayanya cukup mahal (Febriana 2019). Para tamu juga menggunakan pakaian yang senada dengan konsep perayaan yang telah ditentukan. Perayaan ini digelar dengan tujuan untuk berkumpul mengakrabkan diri, saling berbagi pengalaman dengan para sahabat sebelum menikah (Uswatun 2018), dan acara seperti ini sangat menjamur diposting di media-media sosial, terutama Instagram.

$$
\text { Meski dalam perayaannya }
$$

mengeluarkan biaya yang cukup besar karena melibatkan party planner atau event organizer, namun perayaan ini semakin marak dilakukan. Menurut Jayanti (2017), pada lima tahun terakhir perayaan bridal shower semakin booming, khususnya bagi kalangan menengah ke atas. Perayaan ini juga sebagai ajang untuk memeroleh popularitas atau pengakuan diri atau kelompok sebagai orang kota yang mengikuti perkembangan zaman dan sebagai ajang menyosialisasikan peralihan status dari lajang menjadi menikah (Yuwono 2019).

Berbagai kajian yang telah dilakukan terkait perayaan bridal shower telah dilakukan, ada yang berfokus pada bridal shower sebagai bentuk solidaritas sosial (Montemurro 2002 dan Fenol 1994), bridal shower sebagai proses peralihan status (Yuwono 2019 dan Montemurro 2002), bridal shower sebagai perayaan popular yang bersifat hedonisme (Febriana 2019, Jayanti 2017, dan Uswatun 2008). Artikel ini berfokus pada perayaan melepas masa lajang yang popular dilakukan perempuan kota Makassar sebelum melansungkan pernikahan ditengatenga prosesi adat tradisioanl pernikahan masyarakat Bugis-Makassar.

Pembahasan dalam artikel ini terdiri dari empat sessi. Sessi pertama mengeksplorasi proses adopsi bridal shower. Pada bagian kedua mengeksaminasi alasanalasan kenapa bridal shower dilakukan. Di bagian ketiga mendemonstrasikan tahapan prosesi bridal shower. Pada bagian akhir artikel ini mengeksaminasi makna di balik perayaan bridal shower, baik bagi bridesmaids maupun bagi bride to be.

\section{Metode Penelitian}

Penelitian ini dilakukan antara bulan Mei dan Juli 2019. Makassar dipilih dengan pertimbangan bahwa Kota Makassar merupakan salah satu kota besar dengan populasi yang cukup beragam dan dengan berbagai fenomena gaya hidup moderen yang sering kali kita jumpai, khususnya terkait dengan perayaan seperti; perayaan ulang tahun, kelahiran, baby shower dan bridal shower.

Mereka yang berpartisipasi dalam penelitian berjumlah 14 orang. Mereka terdiri atas delapan orang sahabat calon pengantin (bridesmaids) yang membuat dan merencanakan bridal shower, empat orang calon pengantin (bride to be) yang telah mendapatkan surprise perayaan bridal shower, dan dua orang penyedia jasa dekorasi (party planner) yang telah berpengalaman selama lima tahun dalam perayaan bridal shower (lihat Tabel 1).

Tabel 1. Informan Penelitian

\begin{tabular}{|c|c|c|c|l|l|}
\hline No. & Nama & Usia & Pekerjaan & Status & Keterangan \\
\hline 1. & Ainun & 23 & Karyawan & Sahabat calon & Mengadakan bridal shower \\
\hline
\end{tabular}


Bridal Shower: Tren Perayaan Melepas Masa Lajang di Kalangan Perempuan di Kota Makassar

\begin{tabular}{|c|c|c|c|c|c|}
\hline & & & swasta & $\begin{array}{l}\text { pengantin } \\
\text { (bridesmaid) }\end{array}$ & pada Desember 2018 \\
\hline 2. & Dita & 22 & Mahasiswa & $\begin{array}{l}\text { Sahabat calon } \\
\text { pengantin } \\
\text { (bridesmaid) }\end{array}$ & $\begin{array}{l}\text { Mengadakan bridal shower } \\
\text { sebanyak } 2 \text { kali pada Desember } \\
2018 \text { dan Maret } 2019\end{array}$ \\
\hline 3. & Galuh & 22 & $\begin{array}{l}\text { Mahasiswa } \\
\text { dan } \\
\text { Selebgram }\end{array}$ & $\begin{array}{l}\text { Sahabat calon } \\
\text { pengantin } \\
\text { (bridesmaid) }\end{array}$ & $\begin{array}{l}\text { Mengadakan bridal shower } \\
\text { pada Desember } 2018\end{array}$ \\
\hline 4. & Hajar & 22 & $\begin{array}{l}\text { Mahasiswa \& } \\
\text { pebisnis } \\
\text { online } \\
\text { (preloved } \\
\text { shopping) }\end{array}$ & $\begin{array}{l}\text { Sahabat calon } \\
\text { pengantin } \\
\text { (bridesmaid) }\end{array}$ & $\begin{array}{l}\text { Mengadakan bridal shower } \\
\text { pada Maret 2016, Juli } 2017 \text { dan } \\
\text { Desember } 2017\end{array}$ \\
\hline 5. & Reni & 23 & $\begin{array}{l}\text { Karyawan } \\
\text { Swasta }\end{array}$ & $\begin{array}{l}\text { Sahabat calon } \\
\text { pengantin } \\
\text { (bridesmaid) }\end{array}$ & $\begin{array}{l}\text { Mengadakan bridal shower } \\
\text { Desember } 2018\end{array}$ \\
\hline 6. & Wini & 21 & Mahasiswa & $\begin{array}{l}\text { Sahabat calon } \\
\text { pengantin } \\
\text { (bridesmaid) }\end{array}$ & $\begin{array}{l}\text { Mengadakan bridal shower } \\
\text { pada juni } 2018 \text { dan Januari } 2019\end{array}$ \\
\hline 7. & Ummi & 24 & Mahasiswa & $\begin{array}{l}\text { Sahabat calon } \\
\text { pengantin } \\
\text { (bridesmaid) }\end{array}$ & $\begin{array}{l}\text { - Mengadakan bridal shower } \\
\text { pada Juli } 2017 \text { dan Desember } \\
2019 \\
\text { - Sahabat calon pengantin } \\
\text { (bridesmaid) }\end{array}$ \\
\hline 8. & Yuna & 22 & $\begin{array}{c}\text { Mahasiswa \& } \\
\text { selebgram }\end{array}$ & $\begin{array}{l}\text { Sahabat calon } \\
\text { pengantin } \\
\text { (bridesmaid) }\end{array}$ & $\begin{array}{l}\text { - Mengadakan bridal shower } \\
\text { pada April } 2019\end{array}$ \\
\hline 9. & Avy & 24 & $\begin{array}{l}\text { Ibu rumah } \\
\text { tangga }\end{array}$ & $\begin{array}{l}\text { Calon pengantin } \\
\text { (bride to be) }\end{array}$ & $\begin{array}{l}\text { - Calon pengantin (Bride to be) } \\
\text { yang mendapatkan Bridal } \\
\text { shower pada april } 2019\end{array}$ \\
\hline 10. & Ayu & 22 & $\begin{array}{c}\text { Mahasiswa \& } \\
\text { ibu rumah } \\
\text { tangga }\end{array}$ & $\begin{array}{l}\text { Calon pengantin } \\
\text { (bride to be) }\end{array}$ & $\begin{array}{l}\text { - Calon pengantin (bride to be) } \\
\text { yang mendapatkan bridal } \\
\text { shower pada april } 2019\end{array}$ \\
\hline 11. & Maul & 23 & $\begin{array}{l}\text { Ibu rumah } \\
\text { tangga }\end{array}$ & $\begin{array}{l}\text { Calon pengantin } \\
\text { (bride to be) }\end{array}$ & $\begin{array}{l}\text { - Calon pengantin (bride to be) } \\
\text { yang mendapatkan bridal } \\
\text { shower sebanyak dua kali pada } \\
\text { april } 2019 \text { dari kelompok } \\
\text { pertemanan SMA dan SMPnya }\end{array}$ \\
\hline 12. & Renilda & 24 & $\begin{array}{l}\text { Ibu rumah } \\
\text { tangga }\end{array}$ & $\begin{array}{l}\text { Calon pengantin } \\
\text { (bride to be) }\end{array}$ & $\begin{array}{l}\text { - Calon pengantin (bride to be) } \\
\text { yang } \\
\text { - Mendapatkan bridal shower }\end{array}$ \\
\hline
\end{tabular}




\begin{tabular}{|c|c|c|c|c|c|}
\hline & & & & & $\begin{array}{l}\text { sebanyak tiga kali pada 14, } 19 \\
\text { dan } 21 \text { April } 2019 \text { dari rekan } \\
\text { kerja, kelompok pertemanan } \\
\text { SMA dan kelompok pertemanan } \\
\text { SMP. }\end{array}$ \\
\hline 13. & Cici & 26 & $\begin{array}{c}\text { Owner@HKD } \\
\text { Decoration, } \\
\text { HKArchitect }\end{array}$ & $\begin{array}{l}\text { Penyedia jasa } \\
\text { dekorasi (party } \\
\text { planner) }\end{array}$ & $\begin{array}{l}\text { - Party planner paket dekor } \\
\text { bridal shower sejak } 2018\end{array}$ \\
\hline 14. & Ika & 24 & $\begin{array}{l}\text { Owner @Party } \\
\text { Planner_MKS }\end{array}$ & $\begin{array}{l}\text { Penyedia jasa } \\
\text { dekorasi (party } \\
\text { planner) }\end{array}$ & $\begin{array}{l}\text { Party planner paket dekor bridal } \\
\text { shower sejak } 2018\end{array}$ \\
\hline
\end{tabular}

Observasi dan wawancara merupakan kombinasi dua metode yang digunakan dalam penelitian ini. Observasi dilakukan dengan mengamati tempat-tempat yang seringkali dijadikan sebagai lokasi perayaan, persiapan perayaan bridal shower yang dilakukan oleh party planner sebelum memasuki acara inti, mulai dari prosesi, alat-alat yang digunakan, ornamen-ornamen dekorasi perayaan bridal shower. Selain itu, observasi juga dilakukan dengan mengamati dokumen pribadi informan dan berbagai bentuk perayaan yang diunggah pelaku di akun media sosial pribadi mereka, seperti; Instagram story (Instastory), IGTV (Instagram TV), Live Instagram, dan Youtube melaui smartphone untuk melihat prosesi pelaksanaan yang dilakukan oleh perempuan. Wawancara secara mendalam dilakukan untuk memeroleh informasi terkait dengan pengetahuan informan mengenai bridal shower, bagaimana prosesi pelaksanaan bridal shower yang dilakukan mulai dari penyusunan konsep perayaan, rundown acara, properti atau alat-alat yang digunakan, waktu pelaksanaan, lokasi perayaan, biaya yang dikeluarkan, prosesi pelaksanaan, orang-orang yang terlibat dalam pelaksanaannya, motif atau alasan melakukan serta makna dari prosesi bridal shower yang dilakukan.

Analisis data yang dilakukan dengan melakukan transkrip dari hasil wawancara dan observasi yang dilakukan. Ini dilanjutkan dengan membaca keseluruhan data, diikuti dengan menemukan tema-tema, seperti bridal shower, alasan melakukannya, prosesi bridal shower, dan makna dari perayaan bridal shower. Ini dilanjutkan melakukan coding terhadap tema-tema tersebut. Selanjutnya, data tersebut dinarasikan yang dilanjutkan dengan memaknai temuan-temuan yang ada.

Informan yang berpartisipasi dalam penelitian direkrut melalui pesan pribadi, chat Whatssapp ataupun dirrect message (DM) Instagram untuk meminta kesediaan mereka setelah mendapatkan informasi dari beberapa teman yang memiliki hubungan pertemanan dengan orang-orang yang telah terlibat dalan perayaan bridal shower. Masing-masing dijelaskan tentang maksud dan tujuan dari penelitian ini. Setelah mereka bersedia untuk terlibat, masing-masing dimintai kesediaannya untuk diwawancarai dan direkam, dan semua menyatakan kesediannya untuk maksud tersebut. Ini dilanjutkan dengan mengatur waktu dan tempat wawancara sesuai kesepakatan bersama.

\section{Bridal Shower}

Istilah bridal shower berasal dari dua kata yakni "bridal" pengantin perempuan, dan "shower" merupakan pancuran atau dihujani. Jadi, bridal shower yaitu adalah even 
pelepasan bagi calon pengantin yang dihujani oleh kebahagiaan, hadiah maupun wejangan atau nasehat-nasehat untuk menjadi seorang istri dan memulai rumah tangga. Bridal shower saat ini dikenal dengan istilah "pesta lajang" karena perayaan ini dilakukan untuk melepas masa lajang seorang gadis (Yuwono 2019).

Bridal shower merupakan perayaan melepas masa lajang yang dikhususkan bagi calon pengantin perempuan. Perayaan ini merupakan bentuk seremoni baru yang melibatkan kelompok pertemanan untuk memberikan kejutan dan pesan ke teman yang akan menikah dan dirayakan beberapa hari sebelum pernikahan dilangsungkan. Dalam perayaan ini sahabat calon pengantin (bridesmaids) merupakan pihak penyelenggara perayaan yang paling berperan dengan memberikan hadiah bagi calon pengantin (bride to be) berupa peralatan rumah tangga, uang, alat elektronik, serta peralatan lainnya yang dapat digunakan setelah menikah.

Bridal shower telah ada sejak tahun 1600 -an di Belanda sebagai tradisi wajib pranikah. Ini diawali dari kisah seorang gadis kaya yang ingin menikah dengan seorang pemuda dari keluarga tukang giling. Namun ayah gadis tersebut berkeinginan menikahkan putrinya dengan peternak babi yang kaya raya dan mengancam putrinya menahan mas kawin apabila keinginannya tidak dituruti sang putri. Mendengar kejadian tersebut teman-teman serta orang-orang desa bersikeras untuk membawakan hadiah untuk mengisi mahar dan membantu gadis tersebut untuk memulai kehidupan pernikahannya. Melihat kejadian ini sang ayah merasa tersentuh oleh sikap manis teman-teman dan orang desa, sehingga ia menyetujui untuk menikahkan dan memberikan mahar yang besar demi memberkati pasangan baru tersebut. Sejak itu, ini menjadi kebiasaan bagi keluarga calon pengantin dan teman-teman untuk "menghujani" calon pengantin dengan hadiah sebelum ia memulai perjalanan baru, yaitu pernikahan (Montemurro 2001:20).

Di Amerika Serikat tradisi ini dimulai di daerah perkotaan pada tahun 1890-an. Tradisi bridal shower sering dijumpai kalangan kelas menengah ke atas. Penggunaan kata bridal shower di media massa mulai muncul di tahun 1904, pada zaman Victoria. Pada zaman tersebut terdapat kebiasan untuk memasukkan hadiah ke dalam payung yang ketika dibuka calon pengantin akan mandi hadiah. Kemudian pada 1930-an, bridal shower telah menyebar ke pedesaan Amerika. Brussel bridal shower dilakukan sejak tahun 1960-an, sedangkan di Inggris tradisi ini sudah ada sejak abad pertengahan di kenal dengan istilah "bride ale" yang artinya "pesta pernikahan pedesaan" Pesta yang diadakan sebelum hari pernikahan, yakni calon pengantin perempuan membuat bir dan menjualnya kepada para tamu dengan harga tinggi.

Di Prancis, bridal shower disebut dengan istilah bachelorette party. Pesta ini "bersifat liar", dimana terdapat penggunaan simbol-simbol seksual yang jelas dan vulgar (Montemurro 2003:4). Sedangkan, bridal shower dalam tradisi Belanda, merupakan perayaan melepas masa lajang yang dilangsungkan oleh sahabat dan teman yang juga melibatkan pihak keluarga dari calon pengantin perempuan.

Di Indonesia, bride to be lebih memilih menggunakan istilah bridal shower dari pada bachelorette party yang mengandung konotasi yang lebih negatif. hal ini dikarenakan pada perayaan bachelorette party biasanya dilakukan di Bar, Klub atau Restoran dengan menghadirkan minuman-minuman beralkohol, terdapat simbol-simbol seksual, dan bersifat vulgar bahkan seringkali melibatkan penari-penari striptis laki-laki untuk menghibur. Hal tersebut bertentangan dengan nilai-nilai dan norma-norma yang 
berlaku di masyarakat. Penggunaan kata bridal shower dipandang lebih aman dari kritikan atau bahkan larangan karena lebih terasa sebagai suatu ritual unik bernuansa kekerabatan, karena pada prosesinya peserta menjamu calon pengantin perempuan dengan makanan dan memberikan hadiah berupa benda khas kebutuhan bride to be.

Namun, beberapa kalangan tetap menggunakan istilah bachelorette party pada bunting flag (peralatan dekorasi berbentuk bendera kecil dengan tulisan bridal shower atau bachelorette party yang di tempelkan kedinding kafé ataupun hotel, dengan tujuan untuk memberikan informasi ke orang lain bahwa di tempat tersebut sedang berlangsung perayaan bridal shower) sebagai dekorasi perayaan. Tampaknya sisi agama dan pandangan budaya sangat berpengaruh dalam pemilihan istilah ini oleh perempuan Indonesia, selain pertimbangan untuk menjauhi masalah yang potensil timbul sebagai akibat penggunaan istilah yang keliru. Bridal shower versi Indonesia dilakukan sebagai ajang berkumpul bersama kelompok pertemanan perempuan untuk mengenang masa awal pertemanan, menguatkannya dengan membuat komitmen baru untuk saling berhubungan setelah mereka berumah tangga dan pelaksanaannya dilangsungkan di kafé ataupun hotel tanpa minuman beralkohol.

Bridal shower mulai marak dilakukan oleh kalangan selebritis dan selebram Indonesia pada tahun 2011. Setidaknya beberapa selebritis dan selebgram merupakan pionir dari kegiatan ini di Indonesia dan menjadi rujukan bagi masyarakat umum, seperti Raisa Adriana, Laudya Cintia Bella, Rachel Venya, Nabila Gardena, Tiara Pangestika, dan Wayan Indah. Ini kemudian disebarkan melalui media Instagram milik mereka atau disebarkan oleh sahabat para selebriti yang hadir dalam kegiatan tersebut. Melalui media ini seremoni tersebut menyebar secara lebih luas dan kemudian menginfeksi kelompok-kelompok perempuan lainnya, terutama para pengguna Instagram.

Sebenarnya, untuk beberapa kalangan, terutama di perkotaan, kegiatan serupa sudah sering dilakukan, namun tidak diberikan lebel. Para kelompok pertemanan yang melakukan kegiatan bridal shower ini berkumpul bersama untuk saling memberikan dukungan kepada teman akrab yang akan melangsungkan pernikahan, tetapi bentuk pelaksanaanya merupakan hasil kesepakatan mereka terkait konsep maupun prosesinya. Dalam perkembangannya, perayaan melepas masa lajang dikemas dengan sangat menarik, baik dari segi konsep acara, prosesi pelaksanaan dan pernak-pernik yang menyertainya. Bahkan kegiatan ini telah menggunakan jasa party planner yang menandakan bahwa kegiatan ini telah dilakukan dengan lebih serius karena melibatkan biaya yang cukup besar dan sudah memiliki format baku, meski tetap dapat dimodifikasi.

Di Kota Makassar, kegiatan serupa mulai marak di tahun 2015 dan terus berlanjut hingga kini dan tampaknya semakin populer. Perkembangan perayaan bridal shower saat ini ditandai dengan bertambahnya intensitas penyelenggaraannya dan tumbuhnya sejumlah penyedia jasa. Intensitas penyelenggaraan bridal shower dilihat dari mudahnya kita jumpai penyelenggaraan acara bridal shower, seperti yang dijelaskan Ika (24 tahun), yang seorang penyedia jasa dekorasi dan pemilik @Party Planner_MKS, berikut ini:

Melihat perayaan bridal
shower saat ini, mulai banyak
sekali mi dilakukan, dulu
sekitar tahun 2015 pas awal-
awalku kerja party planner
yang bridal shower itu rata-
rata dari kalangan selebgram
atau orang kelas atas ji. Tapi
sekarang semuanya mi bisa 
bridal shower, mulai dari kelas atas, menengah, sampai bawah, biasa bikin mi acara begitu karena kalau mau dibilang masalah biaya toh bisa ji diatur menyesuaikan sama konsep perayaannya (Ika 24 tahun, 24 November 2020).

Maraknya perayaan bridal shower saat ini, menyebabkan bermunculannya penyedia jasa bridal shower (lihat Gambar 1). Salah seorang pemilik penyedia jasa tersebut adalah Cici (27 tahun), pemilik @hkd.decoration, menjelaskan bahwa pertama kali ia melihat perayaan bridal shower sekitar tahun 2015 atau 2016, dan ia diminta oleh temantemannya untuk mendekorasi acara tersebut.

Seiring dengan perkembangannya sekitar dua tahun terakhir perayaan bridal shower semakin popular, sehingga di tahun 2018 Cici sebagai owner party planner @hkd.decoration mencoba peruntungannya dengan membuka jasa party planner karena permintaan pasar yang banyak membutuhkan jasa dekorasi. Perusahaannya tidak saja melayani jasa dekorasi untuk paket bridal shower, tapi juga paket mappettu ada, dan aqiqah, birthday party. Namun, dalam lima bulan terakhir ini, permintan untuk jasa bridal shower mendominasi, sebagaimana yang dituturkan Cici berikut ini:

Untuk dua tahun terakhir ini, penyedia jasa dekorasi kita saat ini menyediakan beberapa jasa dekorasi seperti mappettu ada, aqiqah, birthday party, sama baby shower tapi dari beberapa paket dekornya HKD. Lima bulan terakhir ini, memang paling banyak permintaan untuk perayaan bridal shower sekarang karena perayaan tersebut lagi marak-maraknya (Cici, 27 tahun, 22 Juni 2019).

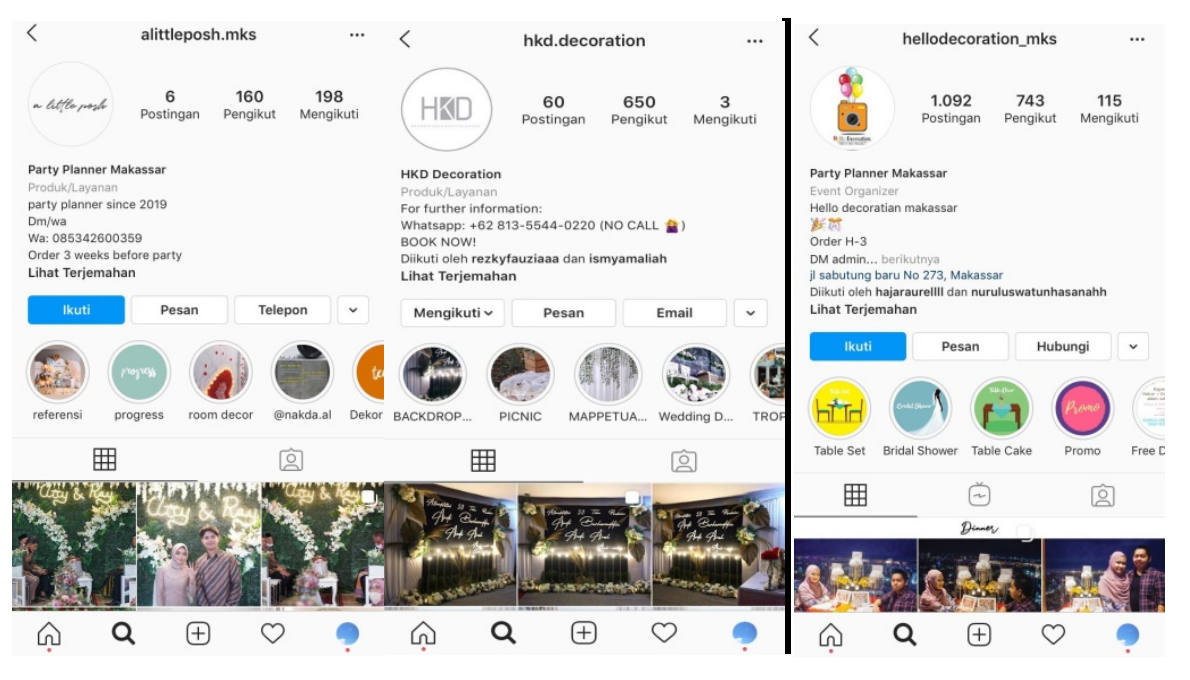




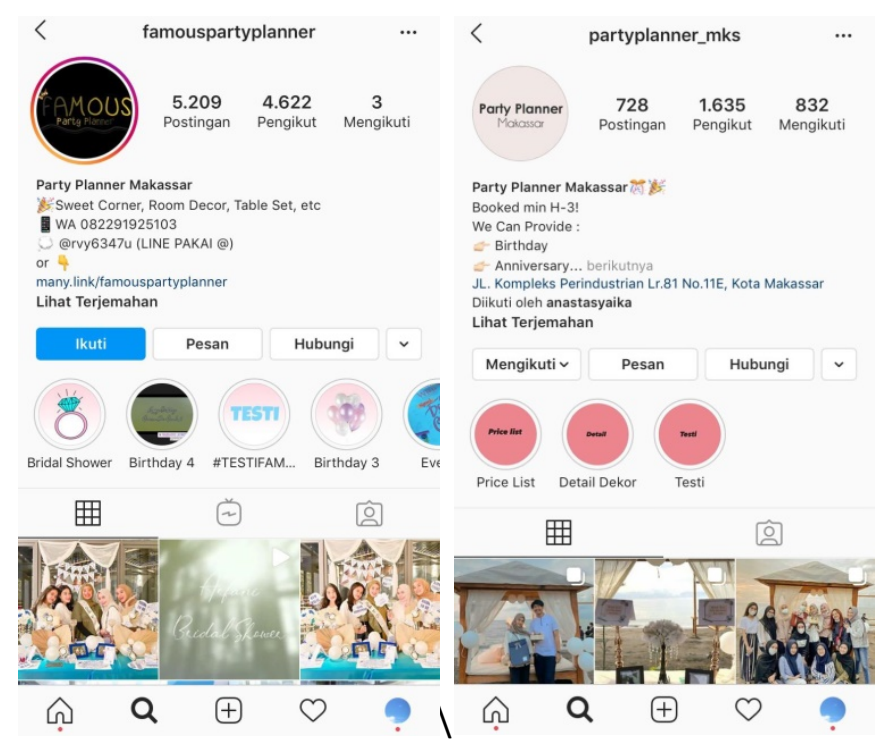

Gambar 1. Akun Penyedia Jasa Dekorasi di Kota Makassar

Sumber: Akun Instagram @Partyplanner_mks, @Famouspartyplanner, mks, @hellodecoration_mks, @hkd.decoration, @alittlepos.mks, 31 oktober 2020

Menjamurnya akun-akun jasa party planner di Instagram mengindikasikan bahwa bisnis penyedia jasa dekorasi untuk perayaan bridal shower saat ini sedang popular. Ini dipengaruhi oleh tingginya permintaan klien untuk melakukan perayaan bridal shower.

Bridal shower bukanlah merupakan seremoni asli Indonesia, tetapi merupakan hasil adopsi dari budaya Eropa, dalam hal ini tradisi perempuan Belanda. Perayaan tersebut kemudian ditiru oleh para selebriti yang memang memiliki kehidupan yang serba glamour. Setiap mereka berusaha untuk tampil beda dengan yang lainnya untuk mempertahankan eksistensi dan terutama untuk mempertahankan para penggemar. Untuk itu mereka harus selalu menampilkan unsur keunikan dan glamour agar tetap dilirik. Penggunaan media sosial untuk mengunggah aktivitas pribadi yang umum dilakukan saat ini memudahkan penyebaran seremoni tersebut. Jika para selebriti menjadikan aktivitas orangorang Eropa dan Amerika menjadi rujukan life style mereka, maka masyarakat di Indonesia menjadikan para selebriti dan public figure lainnya sebagai rujukan, sebagaimana dituturkan berikut ini:
Bridal shower saya lihat dari sosial media toh, yang awalnya Raisa pertama yang begitu. Jadi saya liat $m i$ itu konsepnya apa yang na lakukan. Kan dulu toh kalau ada teman ta kawin palingan datang saja dikasih hadiah, kita $n g g a^{\prime}$ buat kan momen supaya dia bakalan ingat kita, apa lagi sekarang banyak sekali nikah muda, jadi kayaknya waktunya begitu pas banget kalau misalkan anak muda yang nikah dibuatkan bridal shower (Dita, 22 tahun, 25 April 2019).

Saya tau bridal shower dari Instagram, sorry ... Twitter. Twitter sama Instagram. Salah satu selebtweet yang menikah kalau nda salah Arief Muhammad sama ini selebgram. Wedding proposalnya Arief Muhammad sama Tiara Pangestika (Tipang) saya 
nda tau tahun berapa itu di. Intinya pernikannya Arief sama Tipang karena kalau nda salah masih SMA $k a^{\prime}$ nah menikah 2015 saya tau bridal shower dari selebgram ka vbn sebelumnya dia menikah kan banyak itu yang menikah selebgram sama selebtweet itu yang saya liat. Oh sorry, pernah juga saya liat ada akun Twittter yang namanya Audrey teguh anaknya Mario teguh. Nah itu Audrey Teguh datang ke salah satu bridal shower temannya di luar negeri. Nah itu juga saya liat, makanya saya tau ternyata ada perayaan bridal shower pra-nikah ceritanya. Saya kira praweding ji yang ada. Ternyata bridal shower juga ada untuk mengapresiasi yang selama ini terjalin dengan temantemannya dengan memberikan perayaan melepas masa lajangnya (Wini, 21 tahun, 13 Juni 2019).

Kutipan di atas menunjukkan signifikannya peran media sosial terkait konsep, waktu, tempat, serta bentuk perayaan. Seperti perayaan bridal shower yang dilakukan Zazha (21 tahun) dengan sahabat-sahabatnya yang dilakukan dengan meniru acara serupa yang dilakukan oleh Raisa Adriana dan para sahabatnya. Peniruan tersebut berupa konsep, tema, tempat dan waktu pelaksanaan dimana perayaan dilangsungkan di kamar hotel pada malam hari, serta mengusung tema Pajamas. Hal serupa dilakukan oleh Wini (21 tahun) yang meniru bridal shower yang dilakukan oleh Tiara Pangestika dan Audrey Teguh. Contoh lainnya adalah Hajar (22 tahun) yang melakukan perayaan bridal shower dengan meniru Nabila Gardena, seorang selebgram dari kota Bandung yang sangat populer di media sosial Instagram, sehingga bridal shower yang dilakukan Hajar dengan kelompok pertemanannya Ciwit-ciwit Squad terinspirasi dari perayaan yang dilakukan oleh selebgram-selebgram Bandung tersebut.

Peniruan perilaku kalangan atas tersebut dilakukan bertujuan untuk meningkatkan prestise pelakunya di dalam masyarakatnya karena gaya hidup para selebriti dipandang sebagai gaya hidup moderen dan terpandang. Namun demikian, adopsi bridal shower tidak dilakukan secara utuh melainkan mengalami proses penyesuaian dengan menambahkan unsur kreatifitas agar lebih dapat diterima oleh masyarakat Indonesia. Para selebriti, misalnya, tidak menghadirkan minuman beralkohol dan tampilan vulgar dalam acara mereka, sebagaimana yang biasa terjadi dalam bridal shower yang dilakukan di luar negeri.

Perayaan bridal shower memerlukan biaya yang relatif mahal karena biasanya dilakukan di hotel, restoran ataupun kafe, disertai hadiah yang akan diberikan kepada calon pengantin (bride to be) dan pakaian yang akan dikenakan masing-masing bride to be dan bridesmaids. Sementara itu, sarana prasarana, terutama hotel, restoran dan kafé yang tergolong elit berbeda-beda pada setiap wilayah. Untuk pelaku dari kalangan kelas menengah dibutuhkan kreatifitas dari masingmasing pelaku untuk dapat menyiasati keadaan ekonomi dan sarana prasarana tersebut agar pesta tersebut dapat terlaksana tetapi tetap terlihat mewah.

Aspek kreatif lokal pada perayaan bridal shower yang dilakukan perempuan kota Makassar nampaknya sering kita jumpai pada konsep kegiatan yang dilaksanakan dengan tujuan untuk have fun namun tidak melibatkan minuman beralkohol seperti yang dilakukan Yulinar (22 tahun) dalam prosesi 
makan bersama mereka menghadirkan. Ada yang memilih acara yang khidmat, namun ada pula yang membuat yang lebih meriah. Yulinar (22 tahun) menggambarkan bagaimana keseruan acara bridal shower yang mereka lakukan di tepi kolam renang Gammara Hotel untuk seorang teman akrabnya, sebagaimana digambarkannya berikut ini:

Secara kesuruhan sih bridal shower yang saya lakukan sama aja dengan perayaan pada umumnya, mulai dari menutup mata calon pengantin, memberikan wish, makeup in calon pengantin, saya rasa sama-samalah apa yang dilakukan selebritis. Yang beda waktu itu kami sempat menjatuhkan si calon pengantin ke kolam berenang hahaha, karena waktu itu konsep bridal-nya tropical summer theme begitu jadi itu dilakukan di pinggir kolam jadi sesuai kayaknya kalau kita jatuhkan bride-nya ke kolam seru main-main air begitu (Yulinar, 22 tahun 12 Mei 2019).

Berbeda dengan Yuna, Avy yang lebih memilih melaksanakan acara bridal shower dengan konsep yang sederhana (perayaan dengan dekorasi yang simpel, tidak begitu mewah tanpa melibatkan peralatan-peralatan yang berhubungan dengan seksualitas) dan khidmat (prosesi yang dilakukan dengan berkumpul untuk makan bersama, mengenang nostalgia persahabatan, ungkapan pesan dan kesan dan do'a bersama, tanpa melakukan sesi games seperti mencoretmencoret bride to be ataupun games lainnya karena pertimbangan tertentu, seperti yang diungkapkan Avy berikut ini:
Waktu saya bridal itu beda dengan yang lain. Biasanya itu orang dicoret-coret, kalau bridal shower ku dulu itu saya tidak dicoret-coret, temantemanku ji memang nda mau dan saya juga nda mau hahaha. Yah, karena ngapain ikutan orang-orang dek habis itu dicoret dengan gambar yang kotor nda bagus aja, atau pakai kue yang gambargambar tubuh eww, yang kayak biasa saja lebih classy menurutku, yang di coretcoret apalah itu semua terlalu mainstream. Saya pikir juga kalau dilihat keluargaku gimana, soalnya keluargaku tipikal old school banyak aturan hahaha (Avy, 24 tahun,19 Juni 2019).

Kedua contoh kasus di atas menunjukkan bahwa konsep bridal shower dan kegiatan tergantung dari selera yang akan mengadakannya. Meskipun dilakukan secara privat atau tertutup dan hanya dihadiri oleh orang-orang yang saling kenal, namun nilai dan norma dalam hal memperlakukan seseorang tetap ada. Misalnya, dalam kasus Avy yang tampaknya nilai-nilai kesantunan masih sangat diperhatikan, sementara dalam kasus bridal shower yang dilakukan Yuna kegiatan "mengerjai teman" yang umum dilakukan oleh generasi muda saat ini dipandang sebagai sesuatu yang dapat memberikan kesan mendalam. Biasanya acara puncak akan berupa corat-coret wajah calon pengantin, saling melempar kue, mengguyur calon pengantin dengan air dan berbagai bentuk perilaku "gila" lainnya. Di antara kegiatan perayaan bridal shower di Kota 
Makassar dapat dilihat pada Gambar 2 berikut ini.

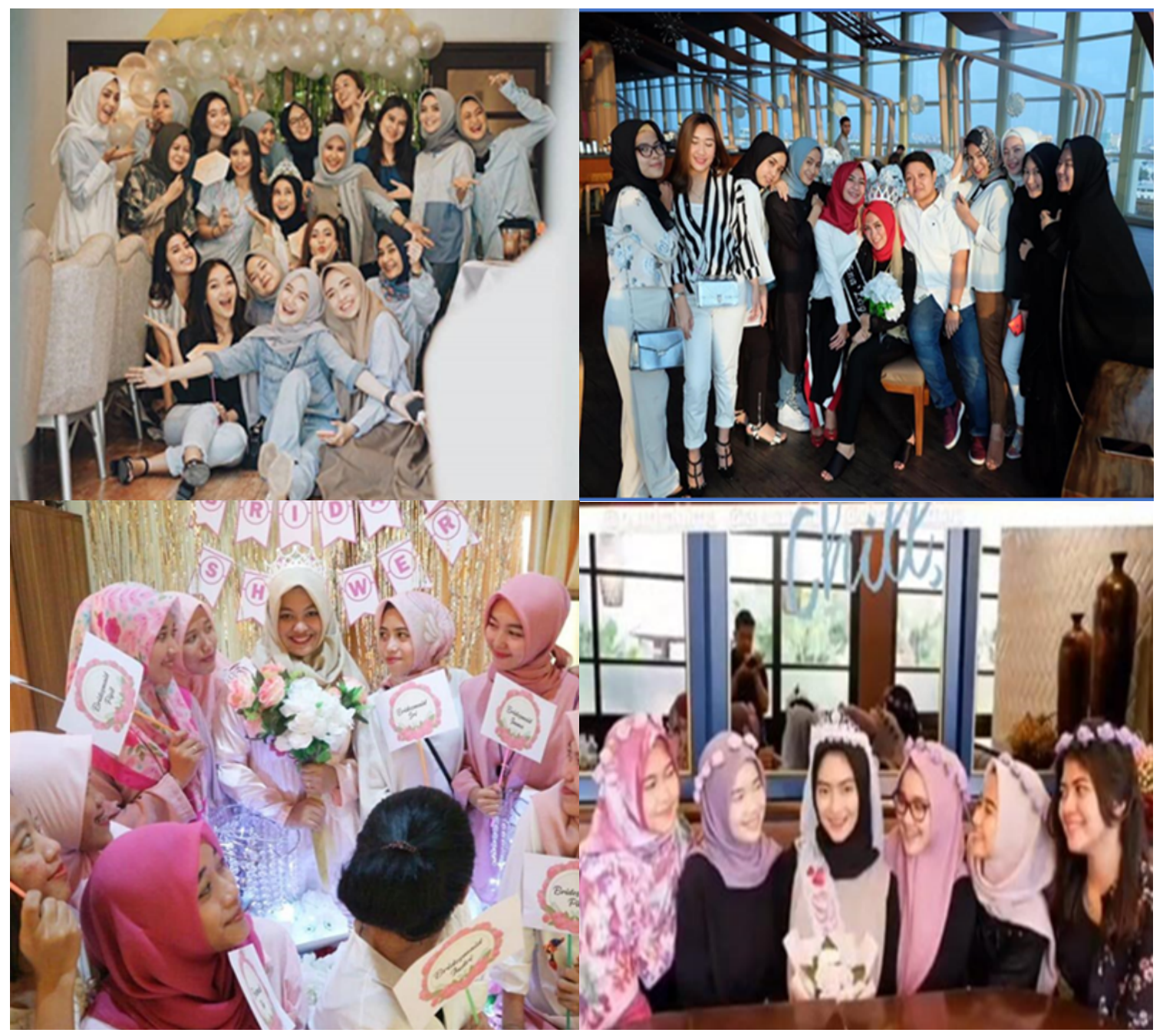

Gambar 2. Perayaan bridal shower di Kota Makassar

Sumber: Instagram @Hkd_decoration dan dokumentasi pribadi informan Galuh (23 Tahun) , 19 April 2020.

\section{Kenapa Bridal Shower Dilakukan?}

Ada sejumlah alasan yang diungkapkan dalam kaitan dengan kenapa bridal shower dilakukan. Alasan-alasan tersebut mencakup adanya kesadaran kelompok, momen "pelepasan" sahabat, dukungan kelompok, mengikuti tren, dan resiprositas, yang akan didiskusikan pada sub-sesi berikut.

Kesadaran Kelompok.

Hubungan pertemanan yang begitu lama dan momen kebersamaan yang seringkali dilalui bersama secara tidak langsung menimbulkan hubungan kedekatan fisik maupun emosional di antara mereka. Kedekatan tersebut menimbulkan adanya kesadaran sebagai anggota kelompok pertemananan, sehingga mereka ver keinginan untuk melakukan sesuatu sebelum seorang sahabat melepaskan masa lajangnya.

Perasaan emosional, yang terjalin di antara kelompok pertemanan pelaku bridal shower yang begitu erat, membuat kelompok pertemanan mereka merasa berkewajiban untuk memberikan perayaan untuk terakhir kalinya kepada salah seorang anggota yang akan melangsungkan pernikahan. Jika 
perayaan tersebut tidak dilakukan, hal ini menimbulkan perasaan tidak nyaman bahkan perasaan bersalah karena tidak memberikan "persembahan terakhir untuk sahabat" yang menjadi salah satu bagian penting dalam hidup mereka. Wini (21 tahun), misalnya, mengungkapkan pertemanannya lebih dari sekedar sahabat, sehingga wajar jika ia diistimewakan jelang pernikahannya, yang dalam hal ini berbentuk bridal shower. Hal serupa diungkapkan oleh Hajar (22 tahun), yang menganggap bahwa persembahan kepada sahabat yang akan menikah (berupa bridal shower) adalah sesuatu yang wajar dilakukan atas nama persahabatan. Artinya, apapun yang dilakukan untuk membahagiakan bride to be adalah sebagai bentuk apresiasi terhadap sahabat yang akan mengakhiri masa lajangnya.

\section{Momen "Pelepasan" Sahabat}

Momen bridal shower hadir sebagai bentuk formalitas pelepasan seorang sahabat ke jenjang kehidupan barunya. Mereka menyadari bahwa setelah menikah akan ada batasan-batasan sebagai konsekuensi status baru, sebagai seorang istri. Oleh karenanya, momen ini dianggap sebagai momen terakhir di antara sahabat untuk melakukan beragam hal secara bersama-sama tanpa ada batasan. Galuh (22 tahun) mengungkapkan bahwa salah seorang sahabatnya "pecah telur" (pemecah rekor). Sebelum pernikahan mereka sudah cukup lama tidak bertemu karena kesibukan masing-masing, terutama bride to be karena mempersiapkan pernikahannya. Oleh karenanya, Galuh dan kelompok pertemanannya berinisiatif untuk melakukan bridal shower.

Bridal shower tidak saja dijadikan sebagai momen pertemuan untuk pelepasan sahabat, momen seru-seruan sebelum masuk ke dunia baru dengan batasan-batasan yang melingkupinya. Bridal shower sebagai bentuk pelepasan terhadap bride to be diharapkan sebagai bentuk "persembahan terakhir" seorang sahabat agar momen tersebut dapat memberi kesan positif dan menjadi kenangan tidak saja bagi bride to be, tapi juga bagi bridemaides.

\section{Dukungan Kelompok}

Pernikahan sebagai salah satu life cycle merupakan suatu hal yang dinantikan hampir semua orang. Peralihan status serta tanggung jawab baru yang akan dihadapi seringkali menimbulkan ketakutan-ketakutan dalam diri calon pengantin, yang diistilahkan oleh Van Gennep (1960) sebagai rites de passage, momen yang dianggap sebagai masa krisis. Pada masa ini, status seseorang menjadi "mengambang", yakni masa peralihan antara lajang dan menikah, antara akan menikah dan belum menikah. Ketegangan ini diikuti dengan ritual yang dipercaya dapat mengeliminir ketegangan yang terjadi pada diri seseorang akibat dari peralihan status tersebut. Maulinar (23 tahun) dan Avi (25 tahun) masing-masing mengungkapkan sebagai berikut:

Waktu itu sebelumku
menikah itu sibuk sekalika'
mana mi mau kuurusi Wo-
ku, tempat menikahku,
undangan, seragamnya
orang-orang, pokoknya
sibuk belum lagi haruska
lembur kerja karena mau
cuti toh, jadi itu waktu
sempatja keteteran untuk
urus ini dan itu sampai-
sampai itu hari bridal
showerku yang kedua
dikasi' sama teman-teman
SMA-ku dirumahku ji,
waktu itu kan masa-masa
sibukku terus datang
teman-temanku ke rumah
itu kayak merasaka' ada
dukungka' ada support dari




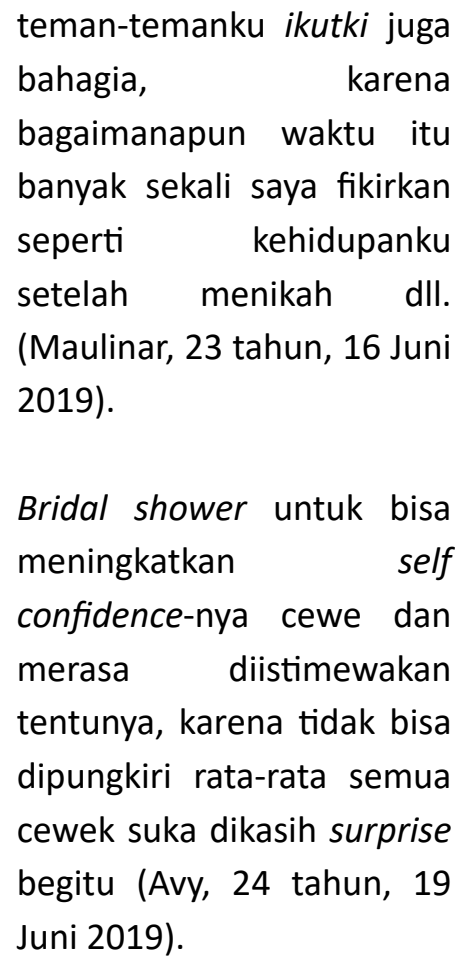

Bridal shower dianggap sebagai bentuk dukungan kelompok pertemanan yang bertujuan untuk membuat calon pengantin merasa lebih tenang, bahagia, dan diistimewakan, serta mengeliminir kegelisahan yang terjadi dalam menghadapi status berikutnya (status menikah), seperti yang dituturkan oleh Ummy berikut ini:

Temanku saja mau menikah itu gugup sekali, tapi kegugupannya itu berkurang gara-gara karena care-nya kita sama dia. Weeee gugup nah pertama dia kayak tegang sekali yang mau menangis terus dia bilang aih jadi $m a^{\prime}, \mathrm{mm}$ istrinya orang, adami tanggung jawabku sebagai istri. Tapi kan dengan adanya kita, jadi kita support $k i$ begitue, jadi makin menerima mi. Jadi pertama kayak gugup sekali, tegang sekali, kita kayak bikin dia rileks
dengan acara ini, tidak
tegang (Ummy, 24 tahun,
16 Juni 2019).

Bridal shower yang

dilakukan kelompokku ini

untuk temanku yang akan

menikah selain sebagai

momen perpisahan, bisa

juga dikatakan sebagai

bentuk dukunganta bahwa

kita ini ikut serta dalam

kebahagiaannya (Galuh, 22

tahun, 16 juni 2020).

Ini menunjukkan bahwa perayaan bridal shower yang dilakukan sebagai bukti dukungan kelompok pertemanan terhadap teman yang akan menikah. Selain itu, perayaan yang dilakukan just for fun, seru-seruan dengan sahabat setidaknya dapat meminimalisir perasaan khawatir dan ketegangan dari bride to be untuk menuju ke status barunya.

\section{Mengikuti Tren}

Tidak dapat dipungkiri bahwa perayaan bridal shower merupakan budaya populer yang banyak diposting di media-media sosial, terutama Instagram. Mereka yang melakukan perayaan bridal shower untuk mengikuti tren karena dianggap bahwa dengan melakukan perayaan tersebut meraka telah dianggap kekinian. Ini diungkapkan dalam beragama ekspresi oleh Wini, Dita, dan Ummy berikut ini:

- Selalu maki lihat yang namanya bridal shower di media sosial, jadi kita juga tertarik untuk adakan itu supaya masa mudanya nda suram-suram banget, flat-flat amat (Wini, 21 tahun, 13 Juni 2019). 
- Di media sosial toh lagi tren ini perayaan, banyak $m i$ kita lihat jadi kayaknya waktunya begitu pas banget kalau misalkan anak muda yang nikah dibikinkan bridal shower. Harapannya yah mengikuti jaman (Dita, 22 tahun, 25 April 2019).

- Dari dulu ji sebenarnya bridal shower, temantemanku yang lain baku bridal shower, selalu mi memang anak-anak begitu karena tren memang toh sekarang (Ummy, 24 tahun, 16 Juni 2019).

Ini mengindikasikan bahwa bridal shower adalah even kekinian (up to date). Dengan demikian, sahabat (bridemaids) dan bride to be sama-sama merasa sebagai orang up to date, yang diekspresikan dengan istilah yang berbeda, beda, yakni: "mengikuti zaman", tidak menjadi bagian dari kesuraman (tidak flat-flat amat), dan mengikuti tren.

\section{Resiprositas}

Umumnya bride to be yang telah mendapatkan bridal shower dari kelompok pertemanannya merasa berkewajiban untuk membalas perayaan tersebut terhadap salah seorang teman yang akan melangsungkan pernikahan dengan membuatkan pula perayaan sesuai dengan apa yang telah diterimanya, sebagai bentuk resiprositas. Calon pengantin menganggap bahwa surprise perayaan ini sebagai suatu hal yang "wajib untuk dibayar", seperti penuturan-penuturan berikut ini:
- Deh dek, malahan kalau ada temanku yang mau nikah kutunggu-tunggu soalnya pengen kasih juga karena sudah $n a$ kasih $k a$ jadi harus saya kasih juga, tidak bisa dipungkiri ratarata semua cewek suka dikasih surprise begitu (Avy, 24 tahun, 16 Juni 2019).

- Kan ini nakasika' temanku otomatis harus kubalas, nda serta merta na kasi' ki ada pasti feedback-nya, ada peka sosialnya karena itu berutangki (Maul, 23 tahun, 16 Juni 2019).

- Kalau itu untuk kasi temanku pasti mi iyya, cuman kembali lagi iyya siapa tau nanti ikut suami ma toh, endak di Makassar ma. Pasti endak bisa lah. Tapi kalau mau ya pasti mau di usahakan (Ayu, 22 tahun, 17 Juni 2019)

Meskipun pertemanan mereka terjalin begitu erat, namun tradisi saling membalas (resiprositas) pemberian tetap berlaku dalam kelompok pertemanan tersebut. Ini sangat dijaga agar tidak menimbulkan kekecewaan antar sesama anggota kelompok. Perayaan bridal shower seperti ini ibarat gayung bersambut ketika ada di antara mereka yang akan menikah. Mereka serta merta merencanakan perayaan bridal shower sebagai bentuk resiprositas bagi sahabat yang telah mendapatkan perayaan bridal shower dan sebagai bentuk apresiasi bagi bagi 
sahabat yang akan menikah dari kelompok pertemanan mereka.

\section{Prosesi Bridal Shower}

Temuan penelitian ini menunjukkan bahwa meskipun juga terdapat variasi dalam pelaksanaan bridal shower, namun secara umum ada lima unsur penting yang tercakup dalam prosesinya, yakni: penyambutan, penyematan atribut, permainan (games), ungkapan pesan dan kesan, dan makan bersama, sebagaimana yang akan dibahas berikut ini.

\section{Penyambutan}

Kegiatan bridal shower melibatkan tidak saja bridesmaids (sahabat calon pengantin), tapi juga bride to be (calon pengantin). Penyelenggaraan acara selalu dimulai dengan penyambutan bridesmaids terhadap bride to $b e$, biasanya disertai dengan kejutan-kejutan. Kejutan penyambutan ini biasanya dilakukan dengan mendatangkan bridesmaids ke kafe/restoran ataupun hotel tempat pelaksanaan acara (lihat Gambar 3).

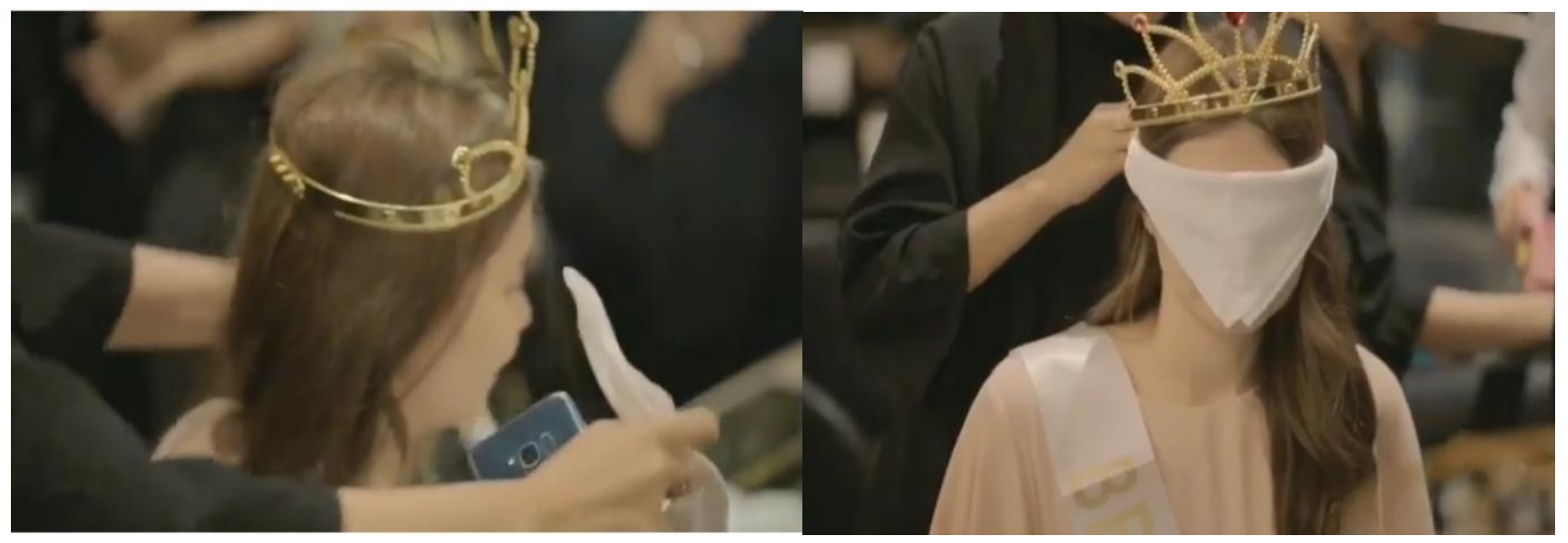

Gambar 3. Bentuk penyambutan bridesmaid terhadap bride to be

Sumber: Instagram @hkdecoration, 25 November 2020

Masing-masing secara kreatif membuat cara penyambutan sendiri-sendiri. Bentuknya beragam, mulai dari bridesmaids membuat jadwal pertemuan dengan bride to be di salah satu kafe, menutup mata bride to be sesaat tiba di lokasi perayaan (seperti nampak pada Gambar 3), memberikan kuis atau tebak-tebakan yang harus di pecahkan oleh bride to be terkait lokasi perayaan bridal shower, hingga menjemput paksa bride to be ke lokasi perayaan.

Jika perayaan dilakukan di kafe/restoran yang dapat melibatkan orang lain, seperti pegawai kafe/ restoran atau hotel, sebagaimana pada perayaan yang dilakukan oleh Wini (21 tahun) dengan kelompok pertemanannya. Penyambutan dengan cara menutup mata calon pengantin dan dituntun menuju kafé atau hotel tempat perayaan bridal shower. Setelah tiba di lokasi perayaan semua sahabat serta karyawan café secara bersama mengucapkan "happy bridal shower" kepada calon pengantin, lagu Rian Midnight berjudul "Marry Your Daughter" sebagai soundtrack yang umumnya digunakan dalam perayaan bridal shower. Setelah itu, bride to be digiring ke tempat duduk yang telah disediakan.

Ini berbeda dengan perayaan bridal shower yang dilakukan Reni (24 tahun) yang berkonsep konsep "White Pink". Kelompok pertemanan ini secara tiba-tiba mendatangi rumah kediaman bride to be, membawanya ke kafe tempat pelaksanaan bridal shower dalam keadaan mata ditutup kain. Setelah tiba di lokasi perayaan beberapa teman mengucapkan kalimat "happy bridal shower". Perayaan bridal shower yang dilangsungkan di 
kamar hotel disertai dengan mendekorasi kamar hotel dengan pernak-pernik bridal shower, seperti bunting flag bridal shower, bunga, serta curtain foil. Setelah itu, dalam keadaan mata ditutup kain, bride to be digiring ke kamar hotel yang telah dihias. Sesampainya di kamar yang dimaksud, penutup mata dibuka dan bride to be diberi ucapan selamat oleh bridesmaids.

\section{Penyematan Atribut}

Pada kegiatan bridal shower, calon pengantin disematkan atribut berupa mahkota dan selempang. Penyematan atribut ini di lakukan ketika bride to be telah memasuki tempat perayaan dan telah menempati posisi tempat duduk yang telah di khususkan untuk calon pengantin. Atribut diberikan agar calon pengantin (bride to be) terlihat menarik, cantik, istimewa, unik sehingga menjadi orang yang menjadi pusat perhatian pada perayaan tersebut. Adapun atribut yang di gunakan bride to be yaitu mahkota dan selempang (lihat Gambar 4).

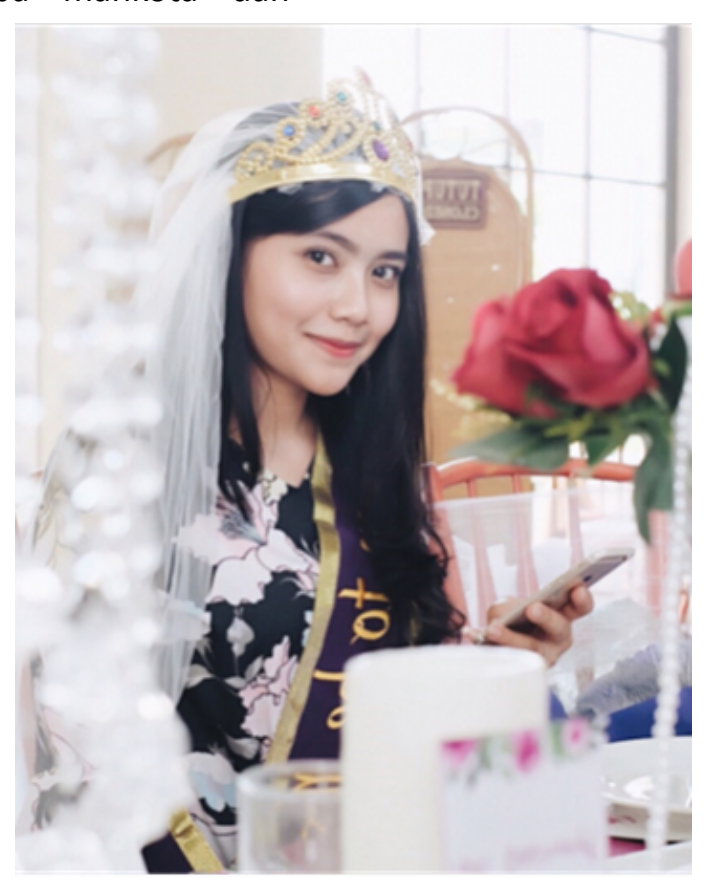

Gambar 4. Calon pengantin (bride to be) dengan atribut bridal shower Sumber: Instagram @avyulviah, 19 April 2020

Atribut yang dikenakan dalam seremoni ini bukan hanya sebagai assesoris semata, melainkan memiliki makna tersendiri. Penggunaan mahkota, misalnya, dimaknai sebagai simbol penghormatan kepada calon pengantin yang akan berpindah status dan pengantin diibaratkan sebagai ratu atau putri yang mulia, memiliki "kedudukan" yang paling tinggi, dan perempuan yang diistimewakan. Selempang adalah assesoris lainnya yang dikenakan bride to be sebagai media untuk menyampaikan pesan atau menggoda bride to be dengan berbagai istilah, misalnya, Bride To $B e$, Wanita Terpinang atau Mrs. Y (nama calon suami), atau kata-kata jenaka yang bersifat "mengejek" seperti Sold Out ("terjual"), Siap Dicocol, Ena' Lagi, dll.

Selain Mahkota dan selempang, untuk konsep perayaan bridal shower tertentu bridemaidss sering kali menyediakan baju (dress ataupun piyama) yang dikhususkan untuk bride to be agar pakaian yang dikenakannya sesuai dengan dress code yang telah disepakati. 


\section{Permainan (Games)}

Bridal shower sebagai perayaan melepas masa lajang biasanya dibuat to have fun, dan salah satu bagian yang penting dalam perayaan bridal shower ini adalah permainan (games). Momen games merupakan momen seruseruan antara bridesmaid dan bride to be. Ada banyak bentuk variasi games yang dilakukan. Namun intinya adalah memberikan perintah kepada calon pengantin untuk melakukan sesuatu dan memberikan hukuman jika ia tidak dapat melakukannya. Permainan yang seringkali hadir dalam perayaan ini cukup beragam, mulai dari mendandani bride to be, tebak-tebakan, Kiss the Miss Good Bye, serta Truth or Dare.

Di antara berbagai games tersebut, mendadani bride to be merupakan hal yang paling umum ditemui dalam perayaan bridal shower. Kegiatan mencoret wajah dilakukan dengan menggunakan lipstik berwarna merah menyala, menggunakan pensil alis, eye shadow, bedak ataupun pewarna lainnya (lihat Gambar 5). Aturan main dalam games ini biasanya bride to be diberikan pertanyaan oleh bridesmaids untuk menguji kedekatan calon pengantin dengan masing-masing anggota kelompok pertemanan mereka. Ketika calon pengantin tidak dapat menjawab pertanyaan yang diberikan para sahabat berkesempatan untuk mencoreti calon pengantin biasanya bridesmaids menggambari wajah bride to be dengan gambar-gambar vulgar, seperti gambar bentuk kelamin lakilaki, kelamin perempuan, payudara perempuan ataupun coretan sesuai kreasi masing-masing bridesmaids. Para sahabat yang terlibat dalam prosesi ini berhak dan berkesempatan untuk mencoreti wajah bride to be, sehingga calon pengantin seringkali menyerupai badut, seperti yang nampak pada Gambar 5 berikut ini.

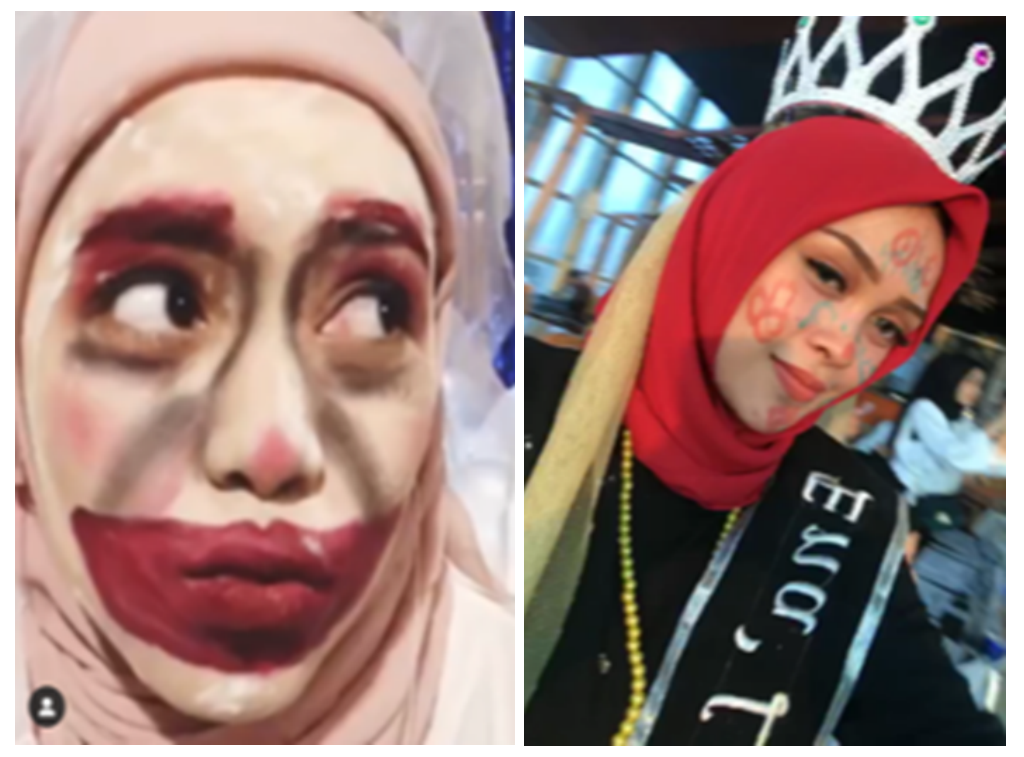

Gambar 5. Calon pengantin dicoreti oleh para sahabat Sumber: Dokumentasi pribadi informan, 2 oktober 2019

Mendandani calon pengantin merupakan ajang untuk menciptakan momen seru-seruan, hiburan, yang diistilahkan "jelek sehari". Momen seperti ini diharapkan akan menjadi kenangan bagi calon pengantin.
Galuh (23 tahun) menjelaskan bagaimana acara tersebut dilakukan kepada salah seorang temannya yang akan menikah: 
Waktu dicoret-coret itu ditutup matanya, istilahnya kayak ini calon pengantin maumi masuk di kehidupan yang baru, rumah tangga toh. Jadi ini ceritanya bentuk pelepasan kayak terakhirmi ini kita seru-seruan, mainmain sama teman-temanya, nakal-nakalnya karena dia sudah mau masuk di kehidupan barunya jadi kita lepas-mi. Kita sadar kalau tidak bisa maki kayak dulu adami batasan, bentuk formalitaslah itu yang dicoretcoret kayak itu-mi terakhir kau dipukul-pukul, dijahili karena kalau setelah menikah tidak bakalan begitumi. Istilahnya itu bentuk perlakuan terakhirmi (Galuh, 22 tahun, 16 Juni 2019).

Selain mencoreti wajah bride to be, aktivitas games lainnya adalah "mengerjai" bride to be dengan mengaraknya berkeliling ke salah satu pusat perbelanjaan (Nipah Mall) dengan wajah yang telah dicoreti, diserta penggunaan mahkota dan selempang. Reni menggambarkan acara bridal shower tersebut sebagai berikut:

Calon pengantin dicoreti, setiap orang mendekorasi sendiri muka calon pengantin sesuai dengan kreasi kemudian dibawa ke Nipah Mall dengan muka dicoreti. Mahkota dan selempang dikenakan dan ia diminta jalan dari lantai I sampai lantai atas mushollah kemudian kita ikut di samping calon pengantin. Tujuannya untuk keseruan bersama, kita anggap seru, enak dilihat itumi yang membedakan teman dengan sahabat. Kalau sahabat biar kita bully bagaimana dia pasti sabar. Coba kalau teman biasa pasti baperki. Ada kebahagiaan tersendiri kita kasih begini temanta. Ini membuktikan bahwa kami sayang sama dia (Reni, 24 tahun, 14 Juni 2019).

Kegiatan "mengerjai" teman tersebut sesungguhnya merupakan cara mereka mengekspresikan persahabatan, memberikan kenangan bagi calon pengantin dan akhir dari masa "saling mengerjai". Prosesi yang sama sesungguhnya sering dilakukan pada kegiatan lain, seperti acara ulang tahun. Orang yang berulang tahun disiram air oleh sahabat sendiri atau menceburkannya ke kolam, menyiram dengan tepung dan telur, sebagai bentuk perhatian dan ekspresi rasa sayang seorang sahabat. Kegiatan "mengerjai" bride to be seperti ini tidak ditemukan pada perayaan bridal shower di negara asal acara ini. Kegiatan tersebut murni merupakan kreasi orang Indonesia melalui para selebriti dan selebgram yang kemudian ditiru oleh kelompok pertemanan.

Permainan "Kiss the Miss Good Bye" sering juga dihadirkan dalam perayaan bridal shower yang dilakukan khususnya bagi kalangan selebgram. "Kiss the Miss Good Bye" hadir diawali dari ide kreatif owner party planner@HKDdecoration, pada saat perayaan bridal shower selebgram Wayan Indah Haris. Cici (25 tahun) sebagai pihak party planner yang membuat dekorasi perayaan tersebut menganggap bahwa permainan ini sangat cocok untuk kalangan selebgram yang identik dengan full make up jika sedang menghadiri suatu acara serta penggunaan lipstik yang 
beragam bagi setiap orang, seperti yang dideskripsikan Cici berikut ini:

Awalnya kartu "Kiss the Miss Goodbye" di hadirkan pada perayaan bridal shower selebgram Makassar yang bernama Wayan. Saya ada kan pas bridal shower yang di atas tujuannya lebih kayak kenang-kenangan buat bridenya sih. Dia bingkai dan pajang jadi adalah kenangkenangan pas teman-temanya bikinin bridal shower buat dia. waktu perayaannya Wayan itu, kan selebgram identik dengan full make up, lipstik pun beda-beda. Jadi lucu saja kalau dibuatin ginian (Cici, 27 tahun, 22 Juni 2019).

Pada tahap ini, ada aturan main yang diterapkan. Pihak party planner menyediakan kartu yang bertuliskan bridal shower diikuti nama calon pengantin. Misalnya, "Wayan's Bridal Shower" dan kalimat "Kiss the Miss Good Bye!" (lihat Gambar 6). Kemudian kartu tersebut digilir ke tiap-tiap sahabat yang turut hadir dalam perayaan ini untuk mencium kartu serta menuliskan nama masing-masing pada bagian bawah bekas ciuman tersebut, seperti terlihat pada Gambar 6 berikut ini.

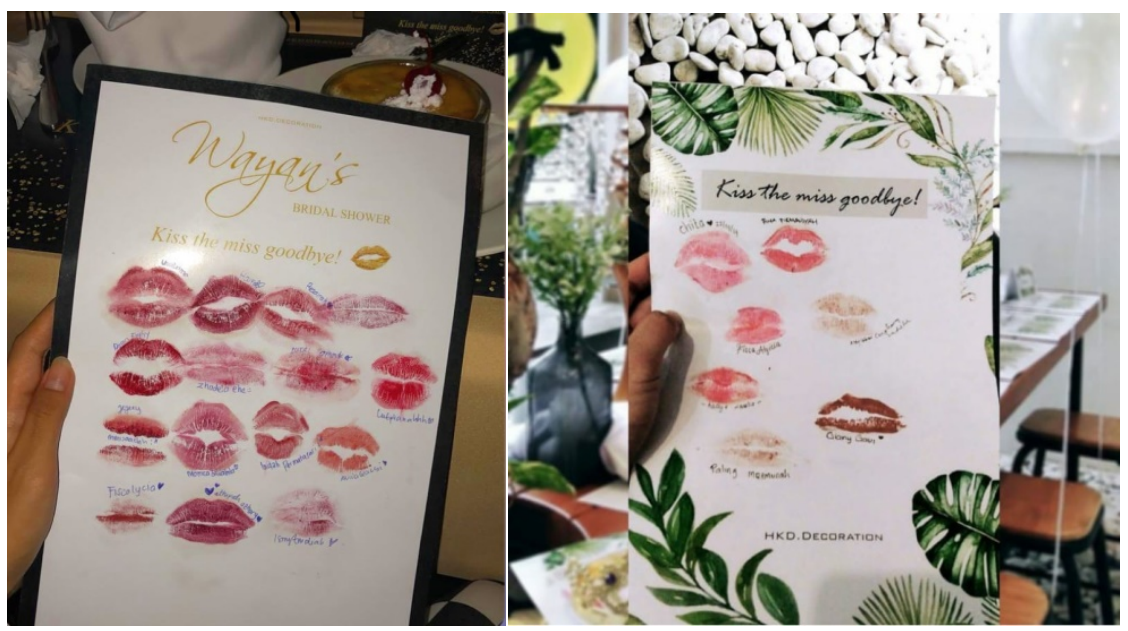

Gambar 6. Kartu the Miss Good Bye

Sumber: Instagram @hkd.decoration, 26 Juni 2020

Kartu "Kiaa the Miss Good Bye" ini dibuat dengan tujuan sebagai kenangkenangan untuk calon pengantin kelak setelah menikah. Kartu ini merupakan bentuk persembahan ciuman terakhir, ciuman perpisahan untuk terakhir kalinya yang diabadikan melalui media sosial yang dilakukan oleh bridesmaid terhadap bride to be.

Permainan lainnya yang juga sering dilakukan adalah Truth or Dare. Permainan ini biasanya dilakukan oleh kelompok pertemanan dengan menggunakan kartu Truth or Dare ataupun melalui aplikasi Truth or Dare dari ponsel pribadi (lihat Gambar 7). Aturan dalam permainan ini dimana masingmasing peserta mendapatkan giliran untuk harus memilih antara jujur atau berani. Ketika peserta game ini memilih Truth (jujur) maka peserta lainnya memberikan pertanyaan yang harus dijawab jujur oleh peserta yang mendapatkan giliran. Adapun pertanyaan yang sering kali diajukan adalah hal-hal yang bersifat privat dari peserta games tersebut. 
Misalnya, nama mantan yang masih diharapkan? Orang yang paling disukai? dll. Selanjutnya, ketika peserta lebih memilih Dare (berani) peserta yang mendapat giliran diberi tantangan yang telah disepakati oleh pemain lainnya. Misalnya menelpon dengan mencari nomor kontak secara acak yang ada dalam telpon selluler, melakukan hal konyol d itengah keramaian, dll.

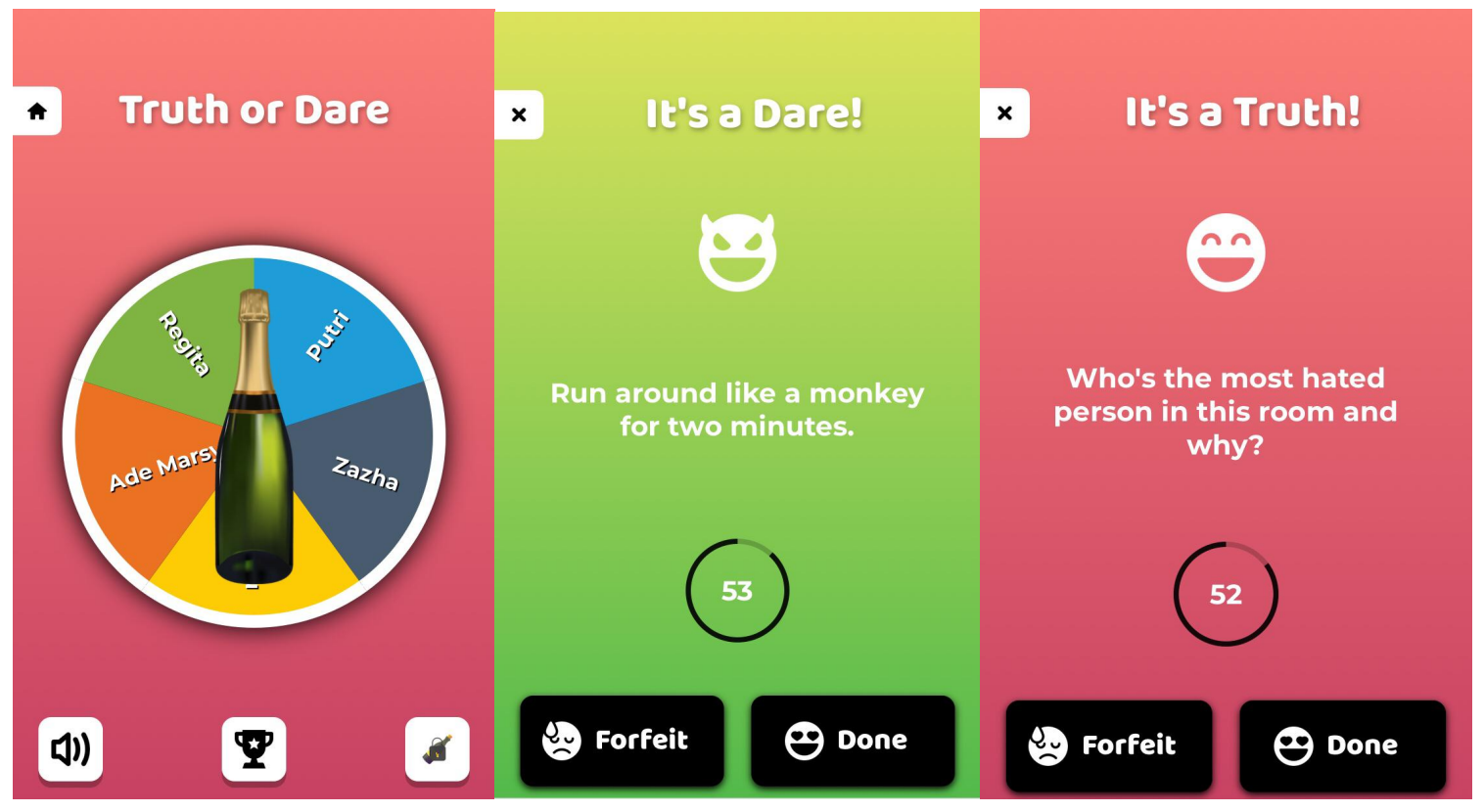

Gambar 7. Aplikasi Games Truth or Dare

Sumber: Dokumentasi peneliti, 30 Oktober 2020

Semua jenis permainan yang dilakukan dalam perayaan hanya semata-mata untuk memeriahkan perayaan dan sebagai bentuk hiburan bagi bridesmaids dan bride to be. Games yang dilakukan setiap perayaan bridal shower berbeda-beda satu sama lain tergantung dari kesepakatan dan kreatifitas dari kelompok pertemanan yang menyelenggarakan perayaan bridal shower.

\section{Ungkapan Pesan dan Kesan}

Salah satu tujuan bridal shower adalah memberikan pesan "perpisahan" kepada sahabat yang akan menikah. Setelah menikah, pertemanan mereka masih akan berlanjut namun intensitas pertemuan akan menurun, apalagi jika bride to be pindah ke daerah lain. Oleh karena itu, dalam kegiatan ini bridesmaids menggunakan momen ini untuk memberikan kesan dan pesan. Kegiatan ini merupakan momen paling mengharukan bagi calon pengantin dan sahabatnya. Para sahabat memberikan kesan-kesan mereka selama pertemanan kelompok tersebut serta berdo'a bersama untuk kehidupan calon pengantin selanjutnya. Momen ini sebagai bentuk "perpisahan" karena adanya batasan kelak antara bridesmaids dan bride to be setelah melangsungkan pernikahan.

Selain pemberian kesan dan pesan, kegiatan memberi hadiah kepada calon pengantin juga dilakukan. Kegiatan memberikan hadiah ini diilhami oleh sejarah lahirnya bridal shower sendiri (baca sessi Bridal Shower di atas). Pemberian hadiah dimaksudkan agar benda tersebut dapat dimanfaatkan oleh bride to be. Adapun bentuk-bentuk hadiah yang diberikan adalah sebagai berikut. 


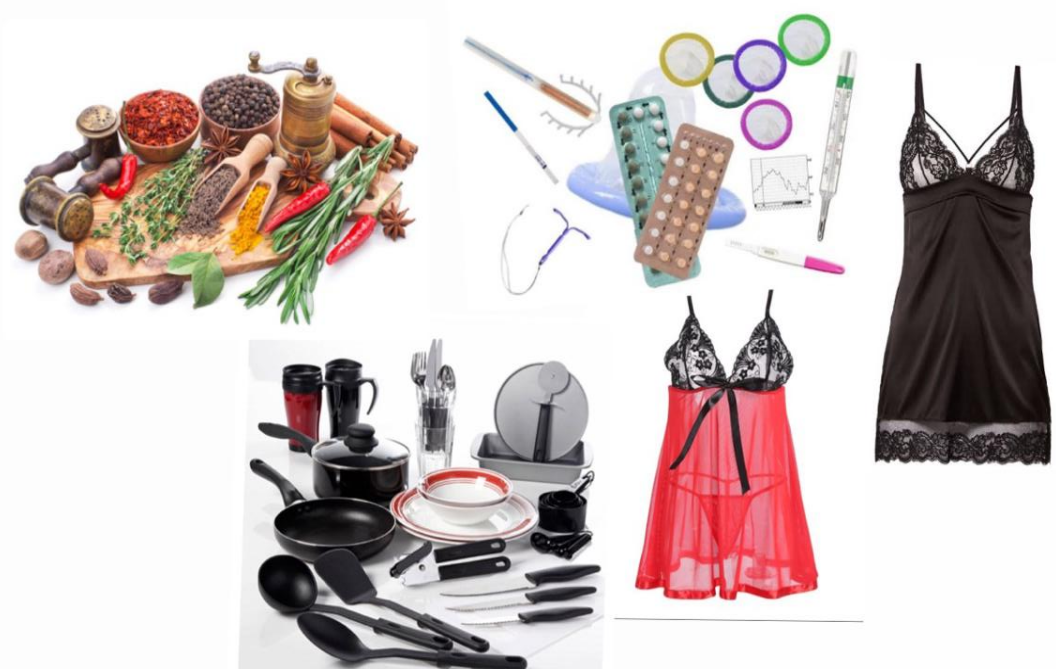

Gambar 8. Contoh bentuk-bentuk hadiah bridal shower.

Sumber: Diadopsi dari Images.Google.com, 24 November 2020

Bentuk-bentuk hadiah yang diberikan berupa peralatan pribadi perempuan, seperti piyama, lingery, daster, sampai alat kontrasepsi (kondom atau pill KB), testpack, dll., peralatan makan dan dapur (seperti sendok atau piring makan, mangkuk, panci, wajan, talenan dll.), kebutuhan harian rumah tangga (seperti sabun cuci dan sprei/bed cover, bahkan hingga bumbu masak (seperti bumbu penyedap, garam, bawang merah/putih, merica, dll.). Jenis hadiah yang diberikan untuk calon pengantin pada prosesi bridal shower merupakan jenis barang yang memang identik dengan status perempuan sebagai istri. Pemberian ini sebagai bentuk peringatan kepada calon pengantin bahwa dia harus bersiap menjadi ibu rumah tangga. Peralatn makan dan dapur mengindikasikan bagaimana bride to be dilihat dalam kaitan dengan peran domestik yang akan dihadapinya.

Hadiah yang diberikan saat perayaan bridal shower memiliki makna tersendiri yang akan disampaikan bridesmaids kepada bride to be. Pemberian hadiah dalam perayaan ini biasanya dilakukan per individu. Masingmasing ridesmaid membawa hadiah untuk bride to be, seperti yang telah dilakukan Wini
(21 tahun) pada perayaan bridal shower salah seorang kelompok pertemanannya. Hadiahnya bervariasi mulai dari lingerie, alat kontrasepsi, bumbu dapur, sabun cuci atau peralatan rumah tangga (seperti panci, piring, mangkuk, dll.). Pemberian hadiah dalam perayaan bridal shower yang dilakukan Wini (21 tahun) dengan kelompok pertemanannya ini merupakan sesuatu hal yang wajib dalam perayaan bridal shower sesuai dengan sejarah hadirnya perayaan ini. Dita (22 tahun) mengungkapkan bahwa pada perayaan bridal shower salah seorang anggota kelompok pertemanannya, mereka patungan untuk membeli hadiah bed cover untuk bride to be.

Namun, pemberian hadiah tidak selalu ada dalam perayaan bridal shower karena semua itu berkonsekuensi dana dan bridal shower itu sendiri sudah merupakan hadiah bagi bride to be. Yulinar (22 tahun), misalnya, mengungkapkan bahwa pada perayaan bridal shower yang dilakukan tidak ada hadiah berupa barang pada saat perayaan, surprice bridal shower yang diberikan sebagai bentuk hadiah yang diberikan bride to be, seperti yang dijelaskan berikut ini: 
Untuk perayaan bridal shower waktu itu tidak ada hadiah yang dikasih seperti kebanyakan orang karena menurutku inimi hadiahnya dibikinkan bridal shower. Terus kita kasih kue ini calon pengantin menurutku inimi hadiahnya perayaan bridal shower-nya. Kalau waktu itu hadiahnya cincin kita kasih pas nikah pi, kan waktu itu selang beberapa hari $j i$ antara bridal shower dan acara nikahannya jadi sekalian di nikahannyapi kita kasih hadiahnya, meminimalisir biaya juga (Reni, 24 tahun).

Pas bridal shower tidak ada hadiah kayak benda begitu. Hadiahnya itu menurutku ini mi hadiahnya yang dipersembahkan untuk calon pengantin dibikinkan surprise. Terus kita kasih kue khusus bride to be, untuk hadiah misalnya cincin kan itu biasa dikasih pas nikah pi, seperti yang biasa dilakukan toh (Yulinar, 12 Mei 2020).

Jika merujuk pada dua pernyataan diatas, maka dalam perayaan bridal shower hadiah bukan merupakan suatu hal yang wajib dan bridal shower itu sendiri sudah dianggap sebagai hadiah. Jikapun ada hadiah tambahan, maka biasanya tidak diberikan pada perayaan bridal shower tapi pada acara pernikahan.
Makan Bersama

Makan bersama merupakan salah satu agenda wajib dilakukan bagi para pelaku, baik di Eropa negara asal perayaan ini maupun di Indonesia sendiri. Biasanya di Eropa makan bersama dilakukan di awal acara ketika tamu undangan telah hadir, hidangan yang dihidangkan bervariasi mulai dari pastry atau hors d'oeuvres, kue-kue, cocktail, ice cream, ataupun minuman beralkohol. Ini dilanjutkan dengan santapan menu utama dan diakhiri dengan sesi game.

Dalam konteks penelitian ini, makan bersama dalam perayaan bridal shower ini dilakukan di akhir acara. Dalam makan bersama ini masing-masing bridesmaids memesan menu makanan sesuai dengan yang dinginkan mulai dari makanan tradisional Makassar, hingga makanan internasional. Makan bersama ini diselingi dengan obrolan santai mengenang momen-momen kebersamaan pertemanan mereka, persiapan acara pernikahan, kendala-kendala yang dihadapi, awal mula pertemuan calon pengantin dengan calon pasangannya, rencana kehidupan setelah menikah, ucapan selamat atas perkawinan yang akan dilaksanakan, doa bersama, dan ditutup dengan sesi foto bersama (lihat Gambar 9). $\mathrm{Hal}$ ini sangat penting sebab ini akan menjadi kenangan untuk semua anggota pertemanan dan akan dibagikan melalui media sosial masing-masing bridesmaids. Untuk mengabadikan momen perayaan bridal shower, bridesmaids tak tanggung-tanggung mengeluarkan biaya untuk menyewa jasa fotogrfer dan videographer untuk mendapatkan gambar dokumentasi perayaan yang baik. 


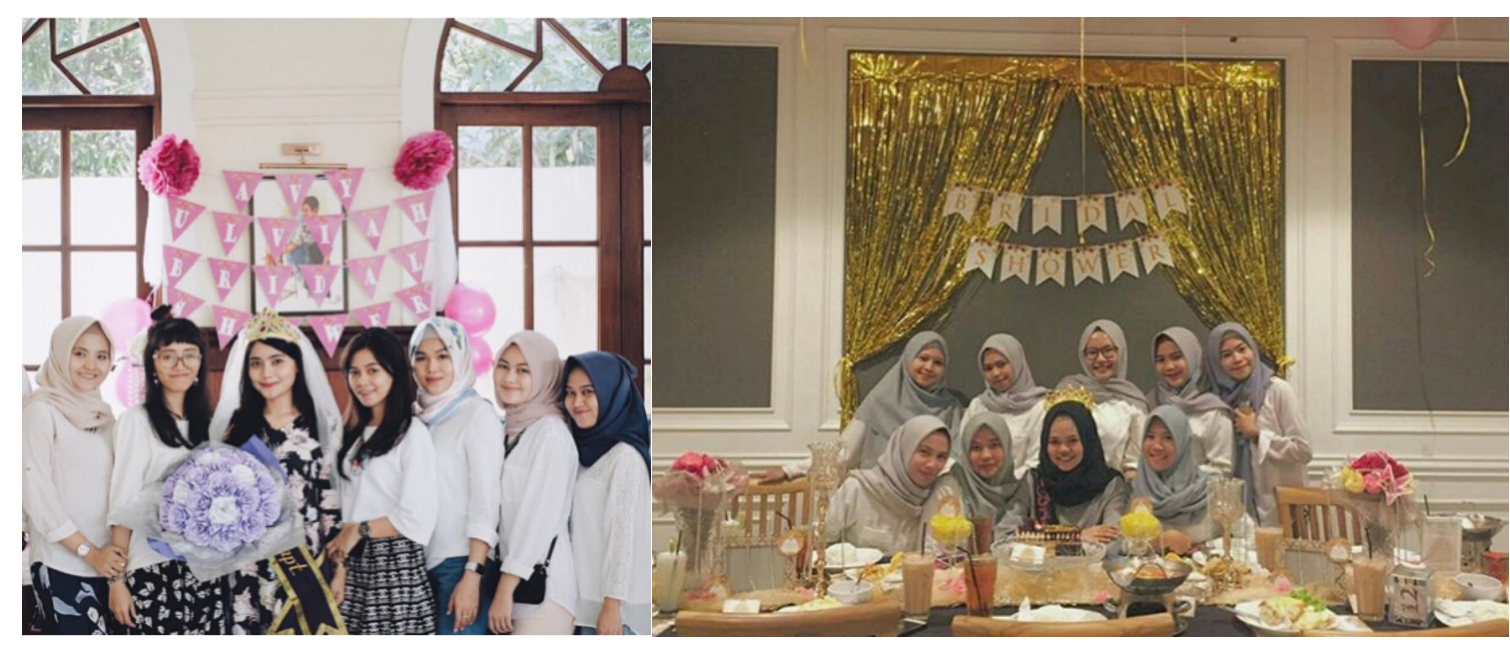

Gambar 9. Foto bersama bridesmaid dan bride to be

Sumber: Dokumentasi pribadi informan Avy (24 Tahun) dan Wini (22 Tahun)

Yulinar (22 tahun), misalnya, mengungkapkan bahwa dalam perayaan bridal shower salah seorang teman kelompoknya, di akhir acara dihidangkan menu makanan has tradisional Makassar, seperti pisang ijo, barongko serta buah-buah segar. Hal ini juga menyesuaikan dengan konsep perayaan yang diusung ketika itu, yakni "summer theme" (tema musim panas). Artinya, ada penyesuaian menu dan tema. Jika seremoni ini dilangsungkan di kamar hotel, maka untuk menikmati makanan utama biasanya dilakukan di restoran hotel. Sementara kue, snack, dan minuman seperti jus, soda biasanya turut dihidangkan di kamar hotel.

Setelah dilakukan makan bersama, yang menjadi penting dan wajib dilakukan sebelum mengakhir perayaan bridal shower yakni sesi foto bersama untuk mengabadikan momen perayaan. Pada kegiatan ini, bridesmaid merupakan orang yang paling istimewah dan menjadi sorotan sehingga pada sesi foto bersama seringkali diposisikan di tengah-tengah antara bride to be. Hasil foto dalam perayaan ini selain sebagai untuk kenang-kenangan juga untuk diunggah disosial media pribadi masing-masing bride to be dan bridesmaid.
Postingan foto di media sosial merupakan sesuatu hal yang dianggap wajib dilakukan bahkan tak jarang pada saat perayaan berlangsung postingan Instastory atau Live Instagram sudah dilakukan karena mereka tidak sa untuk membagi momen keseruan dengan teman-teman di dunia maya.

\section{Makna Perayaan Bridal shower}

Temuan penelitian ini menunjukkan adanya tiga makna bridal shower bagi perempuan Kota Makassar, yaitu: peralihan status, media refleksi dan introspeksi, dan ajang eksistensi kelompok pertemanan di media sosial, sebagaimana yang akan didiskusikan berikut ini.

\section{Peralihan Status}

Seremoni melepas masa lajang atau bridal shower dimaknai sebagai prosesi peralihan status. Bridal shower sebagai seremoni pranikah merupakan ritus peralihan status, dari status lajang ke status menikah. Menurut Van Gennep (1960), semua kebudayaan memiliki suatu kelompok ritual yang memperingati masa peralihan individu dari suatu status sosial ke status sosial yang lain. dalam setiap ritual penerimaan ada tiga tahap: perpisahan, peralihan, dan penggabungan. Pada tahap 
pemisahan, individu dipisahkan dari satu tempat atau kelompok atau status ke tempat, kelompok atau status yang berbeda. dalam tahap peralihan, seseorang disucikan dan menjadi subjek dari prosedur-prosedur perubahan; sedangkan pada masa penggabungan seseorang secara resmi ditempatkan pada suatu tempat, kelompok atau status baru.

Dalam perayaannya, bridal shower sebagai tradisi melepas masa lajang merupakan ritus perpisahan dan peralihan yang ditandai dengan penggunaan atribut/assesoris yang digunakan bride to be serta bentuk-bentuk hadiah yang diberikan sebagai simbol-simbol yang berfungsi sebagai sarana komunikasi untuk menyampaikan pesan-pesan kepada bride to be yang berkaitan dengan kehidupannya kelak setelah menikah.

Pemberian hadiah berupa alat kontrasepsi, testpack, dan lingerie diorientasikan pada kegiatan seksual dan reproduksi, berhubungan dengan hal tersebut sebagaimana yang telah kita pahami bahwa kegiatan seksual hanya bisa di lakukan oleh pasangan yang telah melangsungkan pernikahan. Oleh karena itu, bride to be dipersiapkan secara mental, pengetahuan, dan material dengan pemberian hadiah tersebut.

Selanjutnya, pemberian hadiah berupa peralatan dapur (sendok atau piring makan, mangkuk, panci, wajan, talenan dan lain-lain), kebutuhan harian rumah tangga seperti sabun cuci dan sprei/bed cover, bahkan hingga bumbu dapur (seperti penyedap rasa, garam, bawang merah, bawang putih, merica, dII), diorientasikan sebagai peralihan peran, yang selalu dikaitkan dengan peran-peran di ranah domestik. Ini mempertegas bahwa ranah perempuan adalah ranah domestik.

Pemberian hadiah berupa peralatan pribadi perempuan, alat kontrasepsi dan peralatan rumah tangga dalam bridal shower dimaksudkan sebagai pengingat bahwa perempuan calon pengantin bukan lagi seorang lajang yang memiliki kebesasan melainkan seorang istri dengan tanggung jawab dan peran baru yang diperolehnya.

Bridal shower sebagai ritus peralihan status dimana calon pengantin dipersiapkan oleh kelompok pertemanannya untuk memasuki peran baru di lingkungan barunya. Hal tersebut dimaksudkan untuk mempersiapkan diri menyesuaikan perilaku sesuai dengan nilai-nilai yang berlaku dalam lingkungan baru nantinya.

\section{Media Refleksi dan Introspeksier}

Bridal shower dimaknai sebagai media refleksi bagi kelompok pertemanan khususnya bagi bride to be, hal ini di karenakan pada prosesinya para pelaku masing-masing menyampaikan keluh kesahnya selama menjalin pertemanan, mengingat momen bahagia dan sedih dalam pertemanan.

Selain sebagai media refleksi, bridal shower juga dimaknai sebagai momen saling mengingatkan satu sama lain, khususnya bagi bride to be. Pada momen ini bridesmaids memberikan ungkapan pesan "perpisahan", mengenang kesan-kesan selama pertemanan dan wejangan-wejagan atau nasehat kepada sahabat yang akan menikah dan terkait kehidupan bride to be setelah menikah. Misalnya menaaati perintah suami, mengurus rumah tangga, dan meninggalkan perilaku ketika masih lajang, seperti mengurangi aktivitas di luar rumah, nongkrong, dll. dan harus menyesuaikan peran sebagai seorang istri. Dalam kaitan dengan ini, Maul (23 tahun) menuturkan bahwa:

Sempatka' nangis karena didoakan $k a$. Ada bagian tulistulis apa harapannya mereka ke saya nanti kalau sudah jadi istrinya orang atau nanti bagaimana kalau jauhka 
diambilka sama kakak istilahnya kalau kerja di sana. Ituji yang bikin menangiska karena banyak yang curhat begitu. Pokoknya haruski nabung, haruska jadi istri sholeha. Meskipun keraska haruska tunduk sama suami karena surganya suami itu ada di istri supaya saya bede sama teman-tamanku bisa ketemu di surga karena kalau durhakaka sama suami, nanti tidak bisaka ketemu sama teman-temanku di surga (Maul, 23 tahun, 16 Juni 2020).

Hal serupa juga dilakukan Reni (23 tahun) dengan memberikan pesan-pesan untuk sahabatnya sebagai media refleksi bagi calon pengantin untuk kehidupannya kelak setelah melangsungkan pernikahan, sebagaimana diungkapkannya berikut:

Waktu itu ada momen kita kasih pesan-pesan untuk temanku ini yang mau menikah, kan ini temanku anak anak mama sekali manja nda pernah jauh dari orang tuanya. Terus suaminya ini kan polisi, tugas di Papua Yahukimo tempat terpencil biar Alfamart, Indomaret juga nda ada. Jadi waktu kita tanyami bilang harusko terbiasa sama kehidupanmu nanti kalau, misalnya, nakasih ikutko suamimu, harusko mandiri, dan patuh sama suamimu begitu kita bilang untuk intropeksi diri kalau sekarang nda lajangmi adami tanggung jawab barunya (Reni, 23 tahun, 14 Juni 2019).

Pesan-pesan yang diberikan oleh bridesmaid tidak saja mengindikasikan harapan mereka terhadap bride to be dalam berumah tangga nantinya sebagai media refleksi dan introspeksi bahwa kehidupan rumah tangga berbeda dengan kehidupan lajang, tapi juga bagaimana menjadi istri yang baik, yaitu yang tunduk pada suami yang dikaitkan dengan surga. Wejangan-wejangan serta nostalgia moment kebersamaan masa lalu bride to be dengan bridesmaid menjadikan ajang ini sebagai moment instropeksi diri bagi bride to be agar kelak setelah menikah harus sadar dengan peran dan tanggun jawab barunya serta sadar akan batasan-batasan yang berlaku setelah pernikahan.

Ajang Eksistensi Kelompok Pertemanan di Media Sosial

Bridal shower adalah perayaan yang wajib didokumentasikan karena akan diunggah di media sosial bridesmaids. Melaluinya mereka ingin dianggap tidak ketinggalan zaman, selalu up to date, keren, kekinian (karena telah melakukan perayaan yang saat ini sedang happening di kalangan muda), bergaya hidup moderen dan memiliki jaringan pertemanan yang luas. Oleh karenanya, mengunggah foto dan/atau video momen bridal shower ke media sosial mereka adalah sebuah keharusan, sebagaimana yang diungkapkan oleh Zasha berikut ini:

Semua momen di bridal
shower di-upload, kan
kebutuhan sosmed ji
sebenarnya. Harapannya yah
mengikuti jaman, selain itu
kenangan sebenarnya itu $j i$
iyya. Alasan untuk upload di
Instagram sebenarnya sih 
untuk ala-ala karena popularitas itu penting karena semua orang pasti mau namanya eksis toh, eksistensi itu mau diakui bahwa dia berteman (Zasha, 22 tahun, 25 April 2019).

Maul (23 tahun), yang mendapatkan perayaan bridal shower dari kelompok pertemanannya, mempertegas hal tersebut dengan mengatakan bahwa pengunduhan foto/video di media sosial sarat akan makna. Dari sisi bride to be, pengunggahan foto/video di media sosial adalah sebagai bentuk penghargaan terhadap kelompok pertemanannya yang telah menyelenggarakan perayaan bridal shower. Dari sisi bridesmaids maupun bride to be, pengunggahan foto/video dianggap sebagai ajang untuk menunjukkan eksistensi kelompok pertemanan/persahabatan dan display status sosial mengingat bahwa perayaan tersebut membutuhkan biaya yang cukup besar.

\section{Kesimpulan}

Bridal shower yang merupakan perayaan melepas status lajang yang diadopsi dari budaya Eropa dan Amerika dan telah menjadi bentuk seremoni baru yang diselenggarakan oleh kelompok pertemanan. Ini dilakukan sebagai momen perpisahan dan bentuk dukungan dari bridesmaid sebagai penyelenggara terhadap bride to be yang akan menuju ke kehidupannya yang baru.

Beragam alasan yang mendasari kenapa bridal shower dilakukan, yakni adanya kesadaran kelompok, sebagai bentuk momen "pelepasan" sahabat, sebagai dukungan kelompok, mengikuti tren, dan sebagai bentuk resiprositas. Adapun tahapan prosesi perayaan bridal shower mencakup lima tahap, yakni: dimulai dengan penyambutan bridesmaid terhadap bride to be yang disertai dengan kejutan; diikuti dengan penyematan atribut dengan penggunaan mahkota untuk menunjukkan keistimewaan bride to be dan selendang sebagai media penulisan pesanpesan lucu yang umumnya berkaitan peralihan status dan seksualitas; dilanjutkan dengan permainan (games) yang berupa pertanyaanpertanyaan bersangsi; lalu pengungkapan pesan dan kesan dari bridesmaid kepada bride to be; dan berakhir dengan makan bersama sambil bernostalgia. Meskipun setiap tahap memiliki tujuannya sendiri-sendiri, semuanya dimaksudkan untuk membahagiakan bride to be.

Perayaan bridal shower sarat akan makna, mulai dari peralihan status, sebagai media refleksi dan introspeksi, hingga sebagai ajang eksistensi kelompok pertemanan. Dukungan kelompok pertemanan menjadi sangat signifikan mengingat bahwa peralihan status dan tanggung jawab baru yang akan dihadapi seringkali menimbulkan ketakutanketakutan dalam diri bride to be, sehingga perayaan bridal shower menjadi ritual transisi di masa-masa kritis karena, di satu sisi, bride to be sudah "terikat" melalui pelamaran; di sisi lain, status menikah belum tergenggam, momen yang diistilahkan oleh Van Gennep (1960) sebagai "rites de passage". Perayaan bridal shower adalah momen dimana bride to be meregangkan diri untuk menuju ke status menikah. Bridal shower juga sebagai media refleksi dan introspeksi yang disertai dengan ungkapan pesan-pesan "perpisahan", wejangan-wejagan atau nasehat kepada bride to be. Namun, bridal shower juga merupakan ajang menunjukkan eksistensi kelompok pertemanan melalui pengunggahan fotofoto/video di media sosial dan ajang mendisplay status, bagi bridesmaid maupun bride to be.

\section{Daftar Pustaka}

Creswell, J. W. 2012, Research Design: Pendekatan Kualitatif, Kuantitatif dan 
Mixed (Cetakan II), Yogyakarta: Pustaka Pelajar.

Berardo, F. M. dan Vera Hernan.1981. "The Groomal Shower: Variasi dari American Bridal shower", Family Relations, 30(3):395-401.

Febriana, M. 2019. Hiperrealitas Bridal Shower di Kalangan Perempuan Kota Surakarta. Tesis, Program Studi Magister Sosiologi, Pascasarjana Universitas Sebelas Maret Surakarta, Surabaya.

Finol, jose Enrique. 1994. "the semiotics of contemporary rituals : bridal shower in Venezuela and the United stat", Opcion Apio, 10(15) : 75-91.

Haryono, T. J. (2012). Pengantar Antropologi. Surabaya: Revka Petra Media.

Husain, ST Mutia A. 2012. Proses dalam Tradisi Pernikahan Masyarakat Bugis di Desa Pakkasalo Kecamatan Sibulue Kabupaten. Skripsi, Fakultas IImu Sosial dan IImu politik, Universitas Hasanuddin, Makassar

Jayanti, Febrina Dwi. 2017. Makna Komunikasi Bridal shower di Kota Malang: Studi Pada Pengguna Jasa Bridal shower @Primavera_Event). Skripsi, Universitas Muhammadiyah Malang, Malang.

Kemalasari, Intan. 2015. Tren Bridal shower: Perbedaan Bridal shower diluar negeri dan

Indonesia.http://wolipop.detik.com/w edding-news/d-3070229/ini-bedanyabridal-shower-di-luar-negeri-danindonesia, diakses tanggal 29 Januari 2019.

Koenjaraningrat. 2009. Pengantar Ilmu Antropologi, Revisi 2009. Jakarta: PT. Rineka Cipta
Koentjaraningrat. 1980. Sejarah Teori Antropologi. Jakarta: Universitas Indonesia.

Lexy J. M. 2011. Metodologi Penelitian Kualitatif. Bandung: Remaja Rosdakarya.

Millar, S. B. 2009. Perkawinan Bugis. Makassar: Ininnawa.

Montemurro, Beth. 2001. "'It's Like an Excuse': Normalization and Neutralization of Deviant Behavior at Bachelorette Parties." Paper presented at the annual meeting of the Southern Sociological Society, April, Atlanta, GA.

2002. "You Go 'Cause You Have To": The Bridal shower as a Ritual of Obligation", Simbolic interaction, 25(1):67-92.

2003. "Sex Symbol: The Bachelorette Party as a Window to Change in Women's Sexual Expression", Sexuality and Culture, 7 (2): 3-29.

2005. “Add Men, Don't Sir: Reproducing Traditional Gender Roles in Modern Wedding Shower", Jurnal of Contemporary Etnography, 34(1):635.

2006. Something Old, Something Bold: Bridal shower and Bachelorette Parties. New Jersey: Rutgers University Press New Bronswick.

Putri, A. W. 2018. Di Balik Trend Perayaan Bridal shower.https://tirto.id/di-baliktren-perayaan-bridal-shower-cHKu, diakses tanggal 27 Januari 2018.

Rogers, E. M. dan Shoemaker, F. F. 1971, Communication of Innovation: A Cross Cultural Approach. New York: Free Press. 
Saroya. 2014. Modern Lessons From History: The Bridal shower. http://worldbridemagazine.com/3546 Lmodern-lessons-from-history-thebridal-shower/, diakses tanggal 6 Januari 2018.

Siany L. dan Atiek, C. B. 2009. Khazanah Antropologi Jilid 1. Jakarta: Pusat Perbukuan Departemen Pendidikan Nasional.

Tandyonomanu, D. dan Bahfiarti, T. 2013. "Seni Ruang Dan Waktu Dalam Mappacci Pada Upacara Perkawinna Adat Bugis", Jurnal Kajian Komunikasi, 1(1):83-94 .

Tyie, a Diane. 1998. "Gender, Resistance, and Play: Bachelorette Parties In Atlantic
Canada", Womens studies Internasional Forum, 21(5):551-561.

Uswatun, N. 2018. Pendapat Mahasiswa Tentang Fenomena Bridal shower di Instagram. Skripsi, Fakultas IImu Sosial dan Ilmu Politik, Universitas Sumatra Utara, Medan.

Van Gennep, A. 1960. Rites de Passage (diterjemahkan oleh Monika B. Vizedom and Gabrielle L. Caffee). Chicago: University Chicago Press.

Yuwono, M. F. 2019. Bridal shower Sebagai Gaya Hidup di Surabaya: Studi Makna Ritual Melepas Masa Lajang di Kalangan Wanita Surabaya. Skripsi, Fakultas IImu Sosial dan Politik Program Studi Antropologi, Universitas Airlangga, Surabaya. 